\title{
Personality as an intermediate phenotype for genetic dissection of alcohol use disorder
}

\author{
Lars Oreland $^{1} \cdot$ Gianvito Lagravinese $^{1} \cdot$ Simone Toffoletto $^{1} \cdot$ Kent W. Nilsson $^{2}$. \\ Jaanus Harro $^{3,4}$ - C. Robert Cloninger ${ }^{5}$. Erika Comasco ${ }^{1}$ (i)
}

Received: 2 November 2016/Accepted: 23 December 2016/Published online: 4 January 2017

(C) The Author(s) 2017. This article is published with open access at Springerlink.com

\begin{abstract}
Genetic and environmental interactive influences on predisposition to develop alcohol use disorder (AUD) account for the high heterogeneity among AUD patients and make research on the risk and resiliency factors complicated. Several attempts have been made to identify the genetic basis of AUD; however, only few genetic polymorphisms have consistently been associated with AUD. Intermediate phenotypes are expected to be in-between proxies of basic neuronal biological processes and nosological symptoms of AUD. Personality is likely to be a top candidate intermediate phenotype for the dissection of the genetic underpinnings of different subtypes of AUD. To date, 38 studies have investigated personality traits, commonly assessed by the Cloninger's Tridimensional Personality Questionnaire (TPQ) or Temperament and Character Inventory (TCI), in relation to polymorphisms of candidate genes of neurotransmitter systems in alcoholdependent patients. Particular attention has been given to the functional polymorphism of the serotonin transporter gene (5-HTTLPR), however, leading to contradictory results, whereas results with polymorphisms in other
\end{abstract}

Erika Comasco

erika.comasco@neuro.uu.se

1 Department of Neuroscience, Uppsala University, BMC, Box 593, 75124 Uppsala, Sweden

2 Centre for Clinical Research, Uppsala University, Västmanland County Counci, Västerås, Sweden

3 Division of Neuropsychopharmacology, Department of Psychology, University of Tartu, Tartu, Estonia

4 Psychiatry Clinic, North Estonia Medical Centre, Tallinn, Estonia

5 Department of Psychiatry, School of Medicine, Washington University, St. Louis, MO, USA candidate monoaminergic genes (e.g., tryptophan hydroxylase, serotonin receptors, monoamine oxidases, dopamine receptors and transporter) are sparse. Only one genomewide association study has been performed so far and identified the ABLIM1 gene of relevance for novelty seeking, harm avoidance and reward dependence in alcohol-dependent patients. Studies investigating genetic factors together with personality could help to define more homogenous subgroups of AUD patients and facilitate treatment strategies. This review also urges the scientific community to combine genetic data with psychobiological and environmental data to further dissect the link between personality and AUD.

Keywords Alcohol $\cdot$ AUD $\cdot$ Gene $\cdot$ Personality $\cdot$ Serotonin

\section{Introduction}

Alcohol use disorder (AUD), a psychiatric disorder characterized by excessive and uncontrolled drinking that causes harm and distress, has devastating consequences for men and women of all ages. According to recent statistics, AUD is among the four most disabling diseases, affecting about 14.6 million persons in Europe (Wittchen et al. 2011). AUD is a heterogeneous disorder, which results from the interplay between both genetic and environmental factors (Goldman et al. 2005). To date, there are only four drugs approved by the Food and Drug Administration and four off-label drugs commonly used for AUD, mainly because the putative target(s) and biological underpinnings of AUD are only fragmentarily known (Franck and Jayaram-Lindström 2013; Baingana et al. 2015).

Some aspects related to AUD, such as personality, cognitive function, alcohol metabolism and underlying 
neurophysiology, are partially regulated by genetic factors that likely influence disease susceptibility (Hines et al. 2005). The genetic architecture of intermediate phenotypes, such as personality traits, may be easier to dissect than clinical end points (Rasetti and Weinberger 2011; Meyer-Lindenberg and Weinberger 2006; Almasy 2003). Genetic factors indeed seem to account for one-third to one-half of the inter-individual differences in personality (Slutske et al. 2002) and about 50\% of the heritability of AUD (Goldman et al. 2005). Nevertheless, as AUD is clinically defined, genetic predictors as such may be weaker than clinical ones with regard to prognosis or treatment response. Thus, the investigation of genetic factors together with personality could help define more homogenous subtypes of AUD leading to potential operational diagnostic categories (Fig. 1).

Through the years, many models to classify clinically relevant subtypes have been proposed to improve the clinical management of the patients (Leggio et al. 2009). Particularly, three typologies of alcoholism, e.g., Cloninger's typology, Lesch alcohol typology (Lesch and Walter 1996) and NETER alcoholism typology (Cardoso et al. 2006) have been largely studied in relation to genetic influence, biological markers, personality, clinical features and prognosis (Pombo et al. 2015). Mainly three dimensions of personality have been found to be involved in individuals with AUD, namely impulsivity/novelty seeking, neuroticism/negative emotionality and extraversion/reward dependence [for review; see Mulder (2002)].

Among these, the psychobiological Cloninger's model, built on Swedish adoption studies of children of alcoholics, has been widely studied and validated (Pombo et al. 2015), as in the herein reviewed studies. It defines two alcoholism subtypes, type I and type II, which could be distinguished as having distinct genetic and environmental causes (Cloninger et al. 1981). Type I is characterized by late onset, a low degree of heritability, few social complications and strong environmental influence. Individuals with this type of alcoholism tend to drink alcohol as self-medication. Type II is characterized by early onset and strong genetic influence, comorbid substance use and abuse, and social complications such as a family history of alcoholism, antisocial behavior and depression (Cloninger et al. 1981). Of interest is that these two subtypes are characterized by different personality traits, as shown by Oreland, von Knorring and co-workers in 1985 (Knorring et al. 1985; von Knorring et al. 1991). Cloninger later developed the TCI scale and found that novelty seeking, harm avoidance and reward dependence were associated with dopamine (DA), serotonin (5-HT) and norepinephrine (NA) neurotransmitter systems, respectively. Typical for type I is low novelty seeking (NS), high harm avoidance (HA) and high reward dependence (RD), while individuals with type II have the reverse characteristics: high NS, low HA and low

\section{ENVIRONMENT}
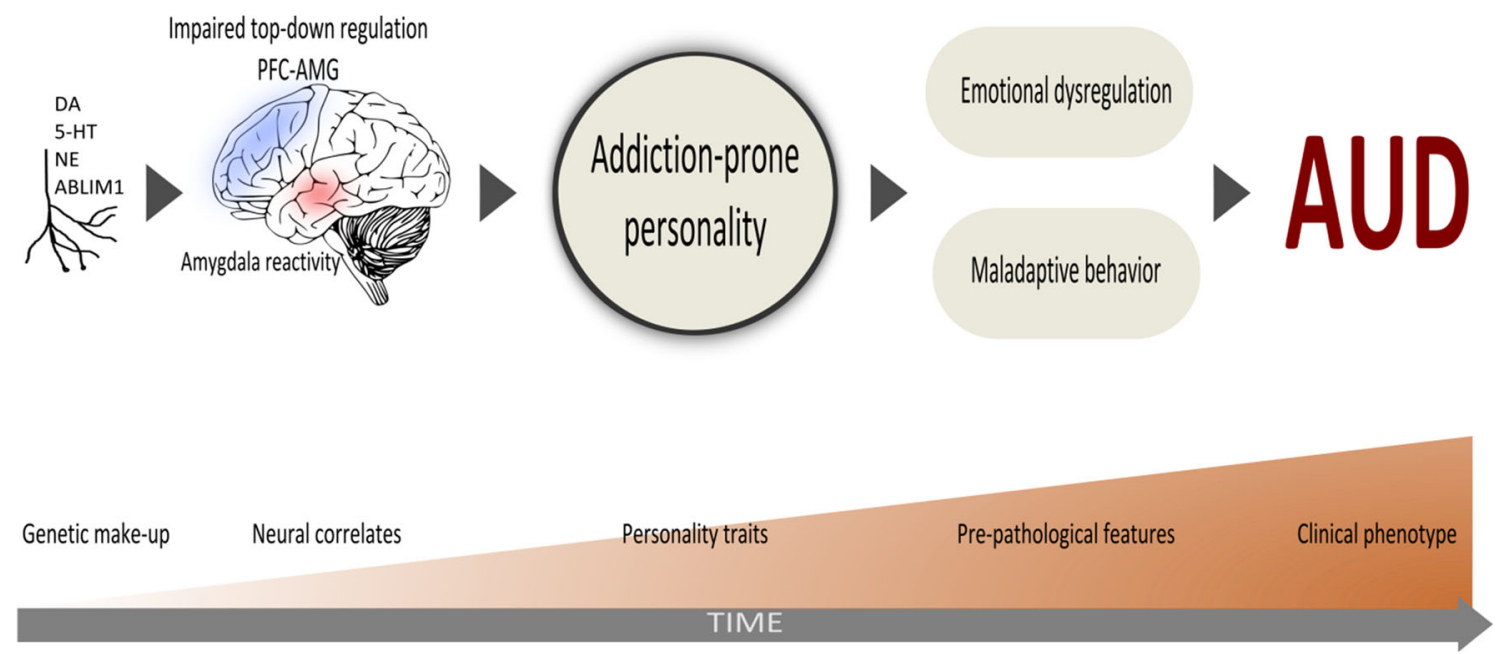

Fig. 1 The proposed study model of personality traits as intermediate phenotype involved in the development of AUD. ABLIM1 Actin Binding LIM Protein 1, AMG amygdala, $A U D$ alcohol use disorder, $D A$ dopamine, $N E$ noradrenaline, $P F C$ prefrontal cortex, 5- $H T$ serotonin 
RD (Cloninger et al. 1996). The predicted role of these temperament dimensions has been confirmed in prospective longitudinal studies of childhood personality (Cloninger et al. 1988), family studies (Grucza et al. 2006) and national probability samples (Cloninger et al. 1995).

A different genetic background may most likely underlie this personality-based dichotomy of AUD. Hence, the purpose of this review is to examine genetic factors contributing to variations in dimensions of personality triggering the development of AUD. Pinpointing genes affecting variations in quantitative measures of intermediate phenotypes such as personality may facilitate the characterization of vulnerability factors.

\section{Materials and methods}

A computerized search of the literature was performed to identify all studies of genetic polymorphism and personality in alcohol-dependent patients (ADP) published before August 2016. Articles have been retrieved from PubMed/ MEDLINE and Google Scholar using the following search terms and relevant combinations of them: "Alcohol", "alcoholism", "genes", "polymorphism", "alcohol-dependent patients", "Alcohol use disorder", "AUD”, "Alcohol personality disorder", "Alcohol intermediate phenotype", "personality substance use disorder", "SUD", "personality traits", "Type 1", "Type 2", "Novelty seeking", "Harm avoidance", "Serotonin transporter gene" and "5-HTTLPR". The list of references cited in the retrieved articles was also used to identify relevant articles. Candidate gene, gene-by-gene interaction $(\mathrm{G} \times \mathrm{G})$ and genome-wide association studies (GWAS), in which the association between genetic variants and standardized measures of personality among alcohol-dependent patients were examined and selected for the present review. For each study, the following information was extracted: first author, publication year, sample size, sex ratio, mean age, ethnicity, clinical diagnosis, personality measure, gene and polymorphism, allele/genotype frequencies by groups and the main findings regarding the association between polymorphism and personality. With regard to personality traits assessment, we included studies that have made use of standardized self-report questionnaires. As the polymorphisms in the serotonin transporter gene (SLC6A4) were the most investigated genetic variants, the studies were grouped into those that explored serotonin transporter-related polymorphisms (Table 1) and those that explored other genetic variants (Table 2). No statistical analyses were performed due to high heterogeneity between the studies.

\section{Results}

\section{Description of studies}

A total of 38 studies investigated the relationship between genetics and personality in alcohol use disorder (Tables 1 , 2 ). The majority of studies recruited either inpatients or outpatients diagnosed with alcohol dependence from clinical settings. Thirteen studies examined samples composed only of males. Alcohol dependence was diagnosed according to DSM-III-R, DSM-IV or ICD-10 criteria. Overall, the samples of ADP were commonly diagnosed with comorbid antisocial (ASPD; DSM)/dissocial (DPD; ICD-10) personality disorder. Four studies assessed samples of alcohol-dependent prisoners with comorbid antisocial personality disorder (Wu et al. 2008; Ducci et al. 2009; Lee et al. 2009; Lu et al. 2012). One study assessed ADP with borderline personality disorder (Preuss et al. 2001) and one assessed ADP with conduct disorder (Soyka et al. 2004a, b).

The sample size ranged from 72 to 1335 ADP, and the weighted mean age was 40.5 years. In most of the included studies, participants were Caucasian. Ten studies included Asian ADP (Han Chinese or Japanese), one investigated a sample of American Indians females (Ducci et al. 2008) and one investigated a sample of Afro-American and Hispanic ADP (Herman et al. 2011).

\section{Personality inventories used in the studies on AUD}

Personality traits were commonly evaluated using Cloninger's Tridimensional Personality Questionnaire (TPQ) (Cloninger et al. 1991) or Temperament and Character Inventory (TCI) (Cloninger et al. 1994). Alternatively, other personality inventories such as the Neuroticism Extraversion Openness Personality Inventory-Five Factor Inventory (NEO-FFI) (Anghelescu et al. 2010; Stoltenberg et al. 2002; Soyka et al. 2002; Koller et al. 2006) and the California Psychological Inventory (CPI-So) (Herman et al. 2011) were used. To measure specific traits, the Barratt Impulsiveness Scale (BIS) (Preuss et al. 2001; Koller et al. 2003; Flory et al. 2011), Buss Durkee Hostility Inventory (BDHI) (Buss and Durkee 1957), Brown-Goodwin assessment for history of lifetime aggression (Balthazart et al. 2004; Soyka et al. 2013; Koller et al. 2003), Sensation Seeking Scales (SSS and ZSS-V) (Zuckerman et al. 1972) (Matsushita et al. 2001; Flory et al. 2011) and California Psychological Inventory (CPI-So) (Herman et al. 2011) were used (Tables 1, 2). 


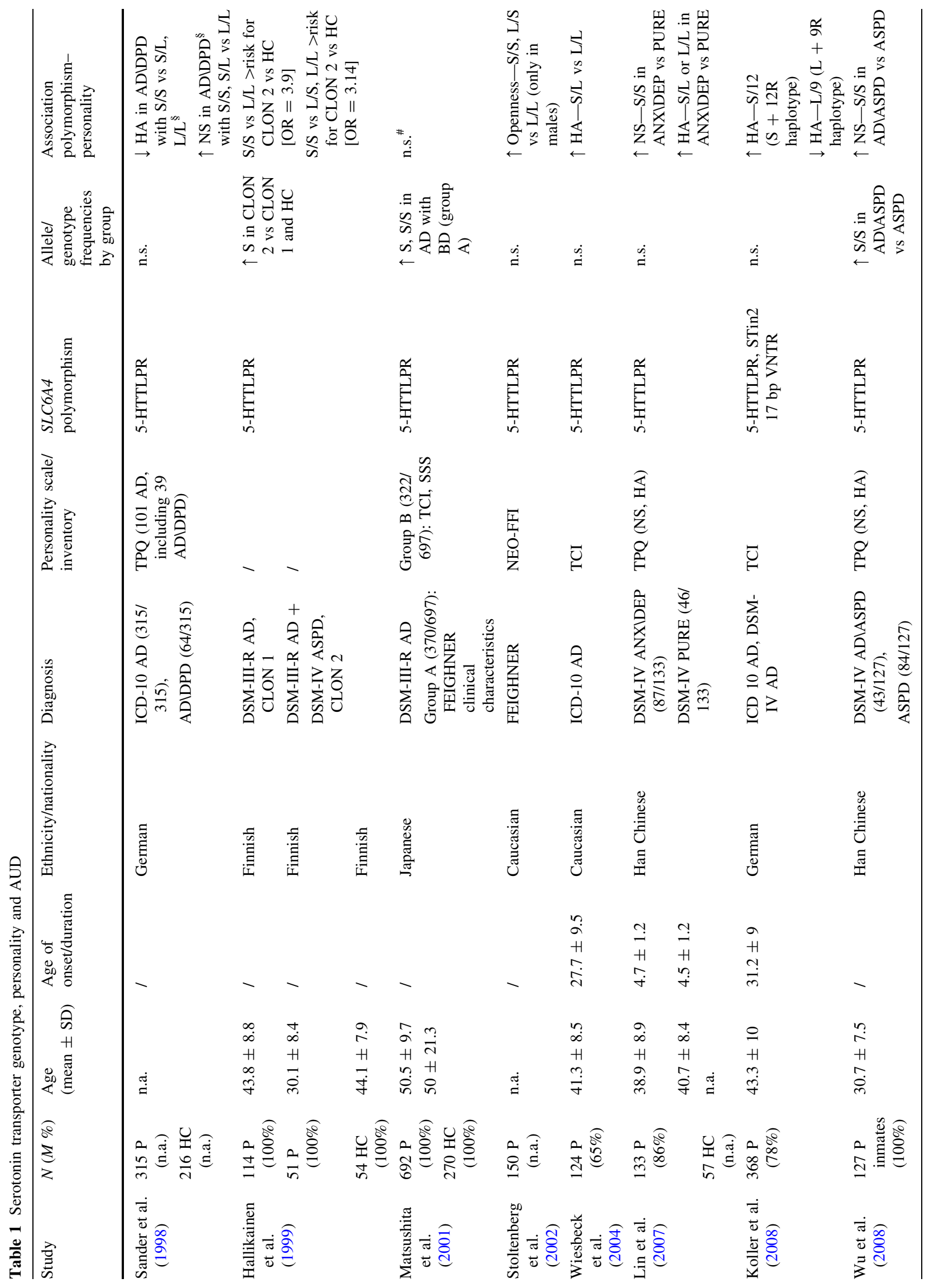




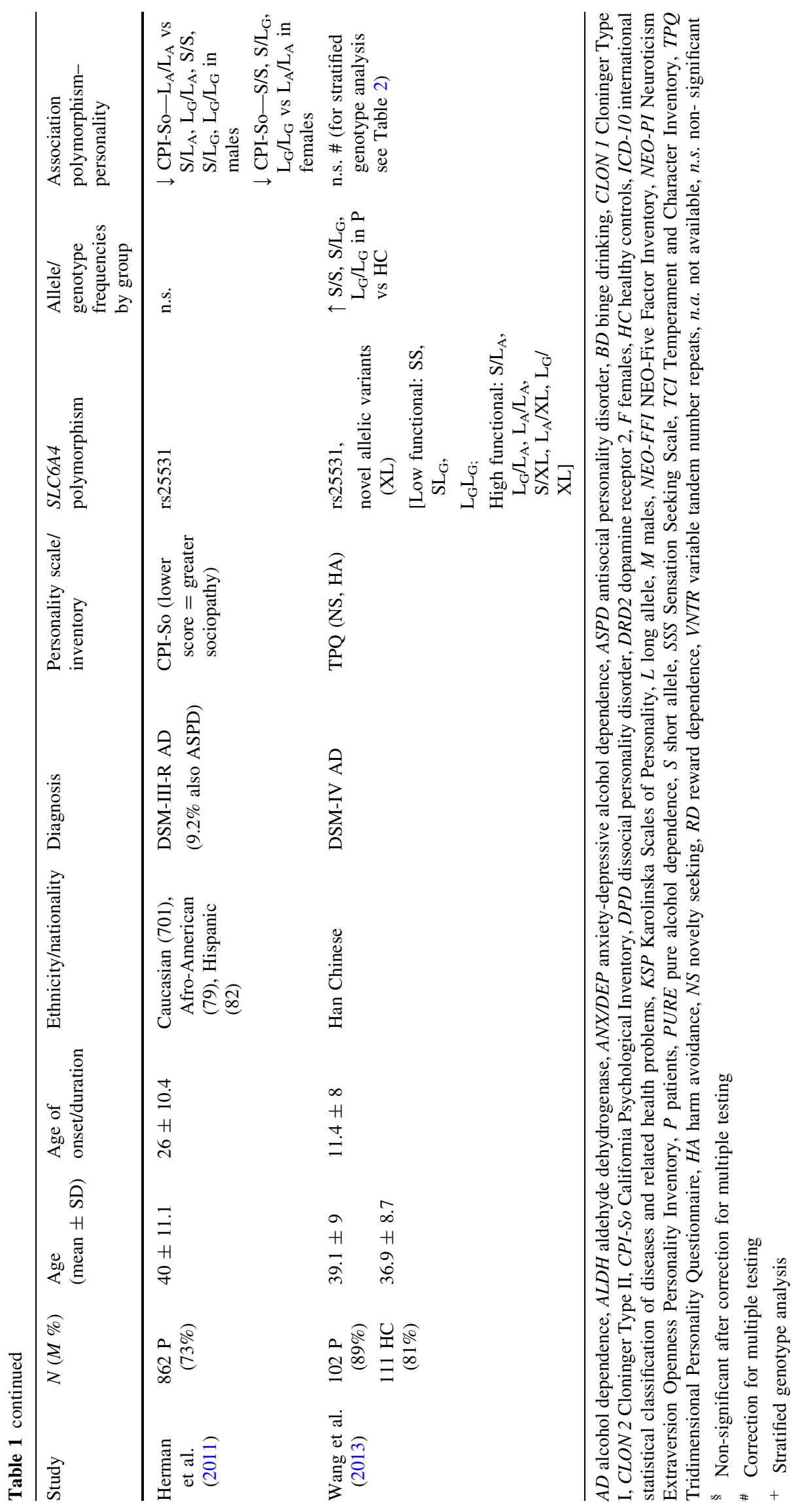




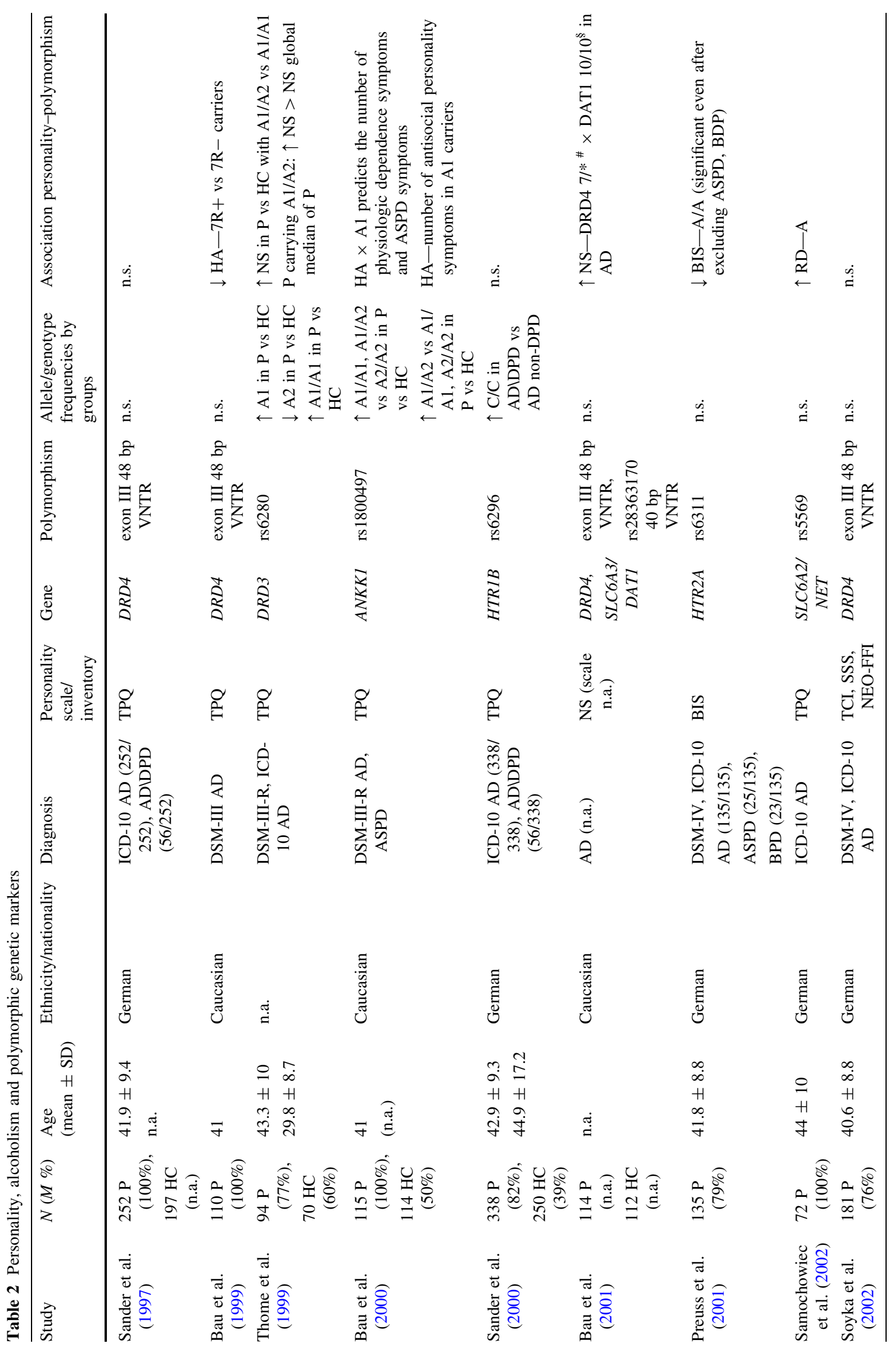




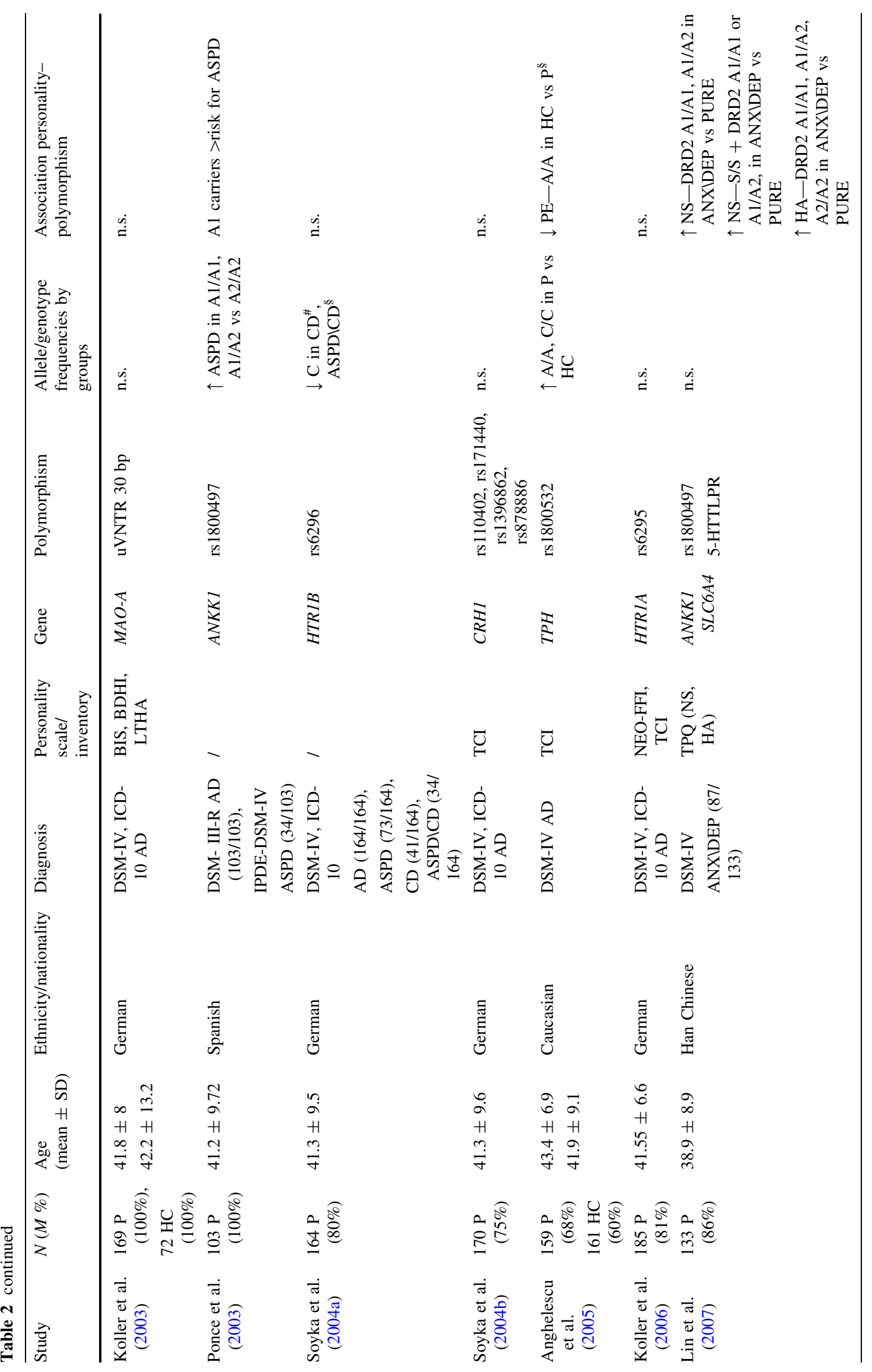




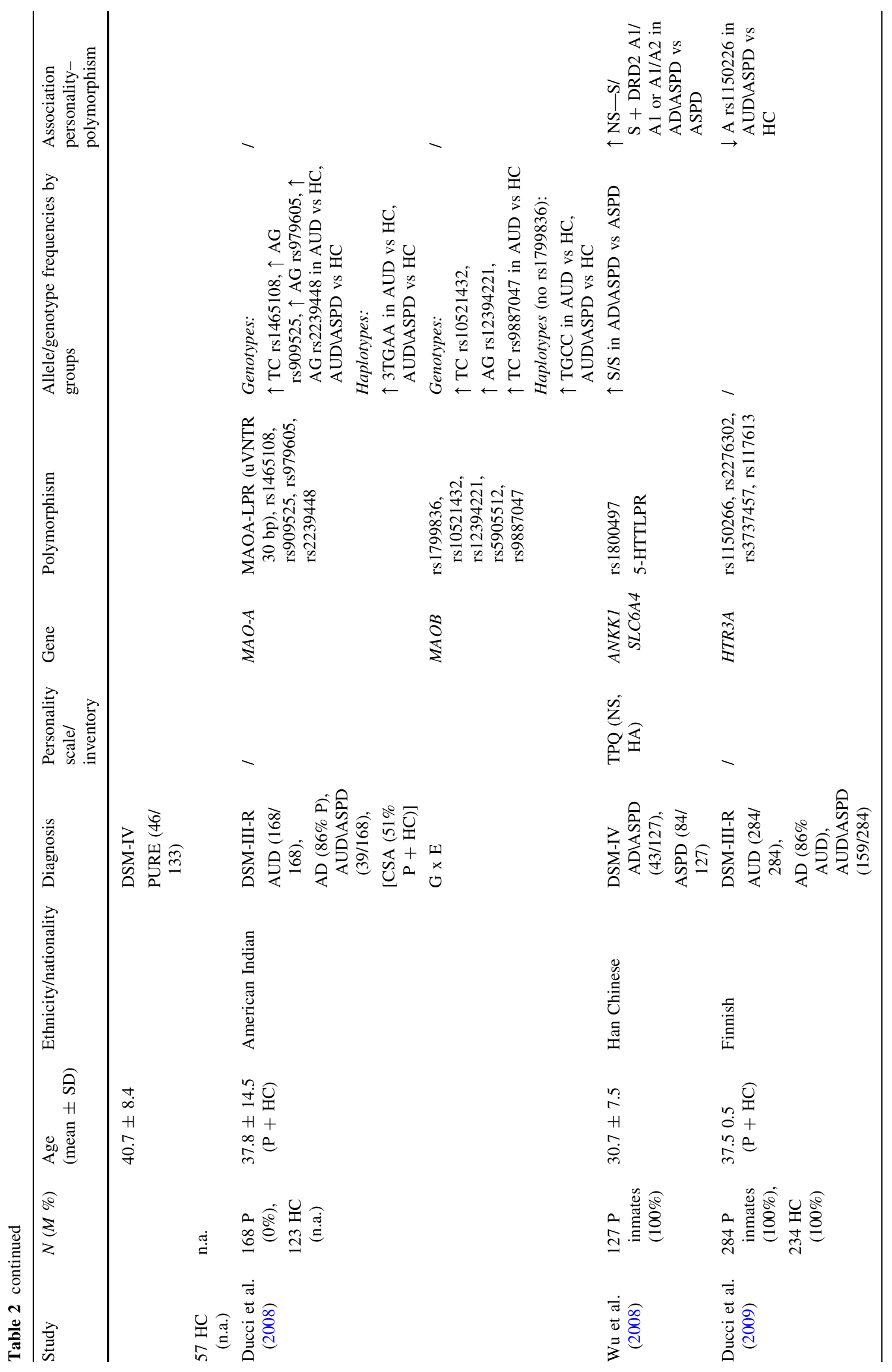




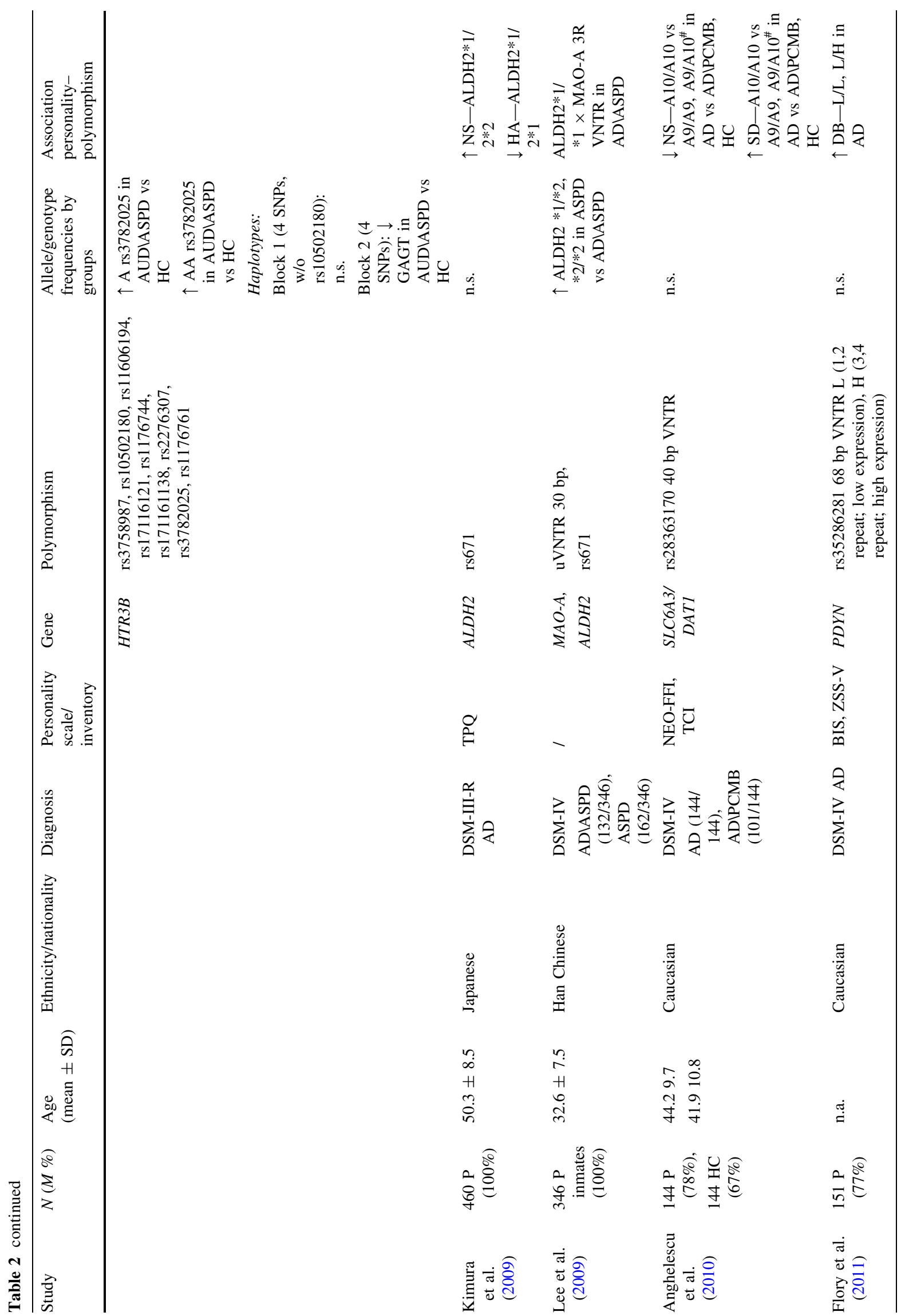




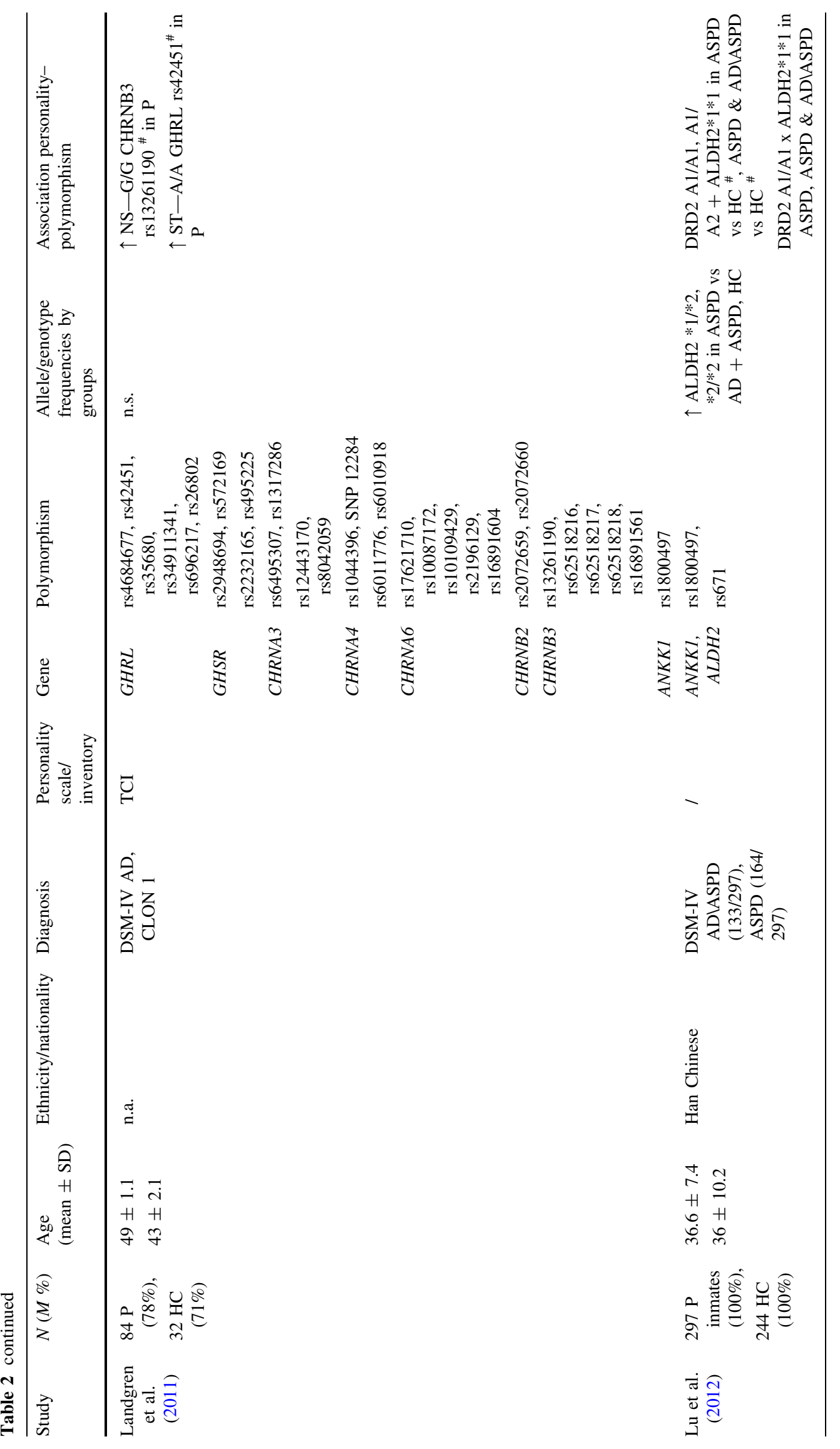




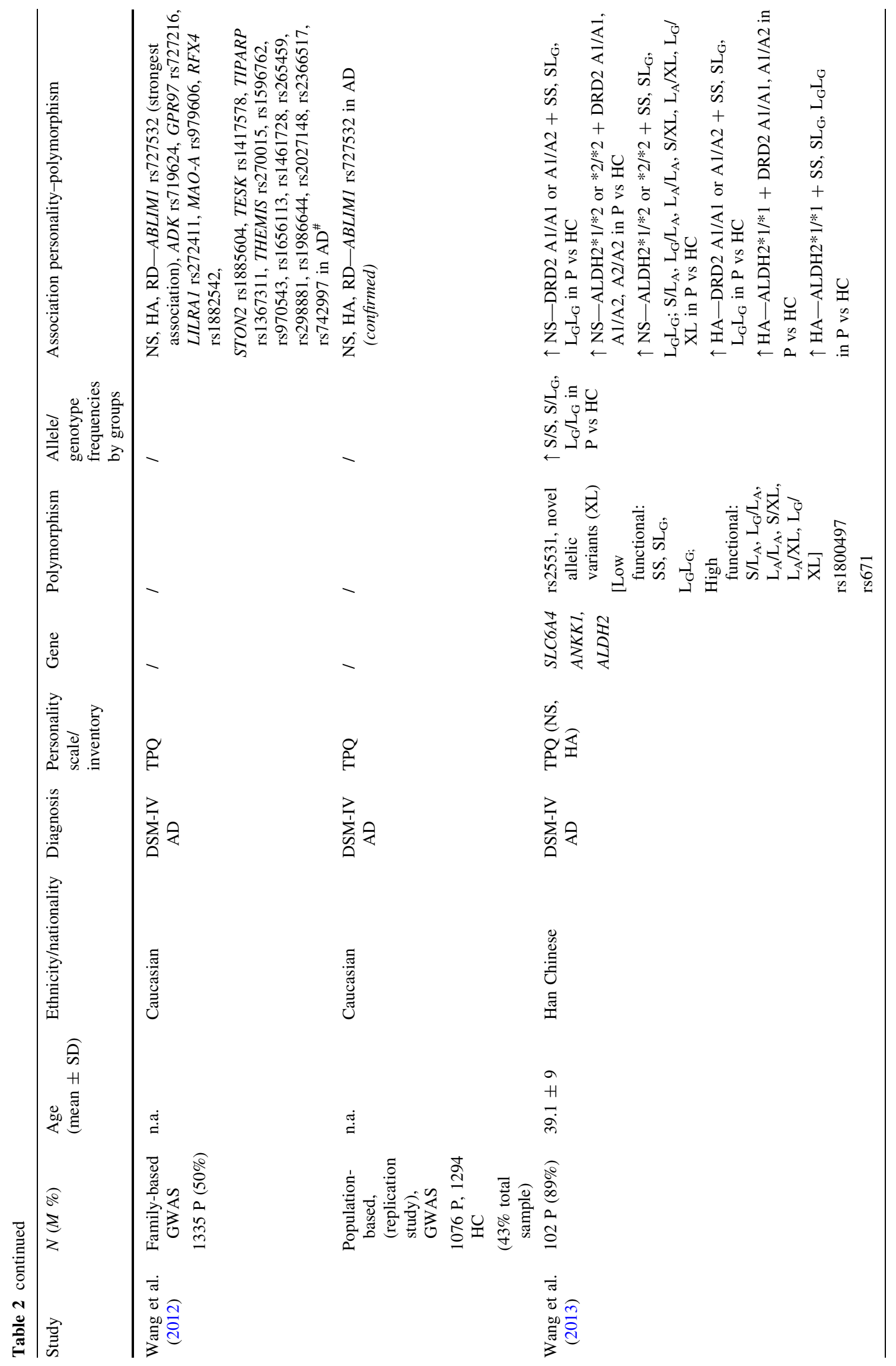




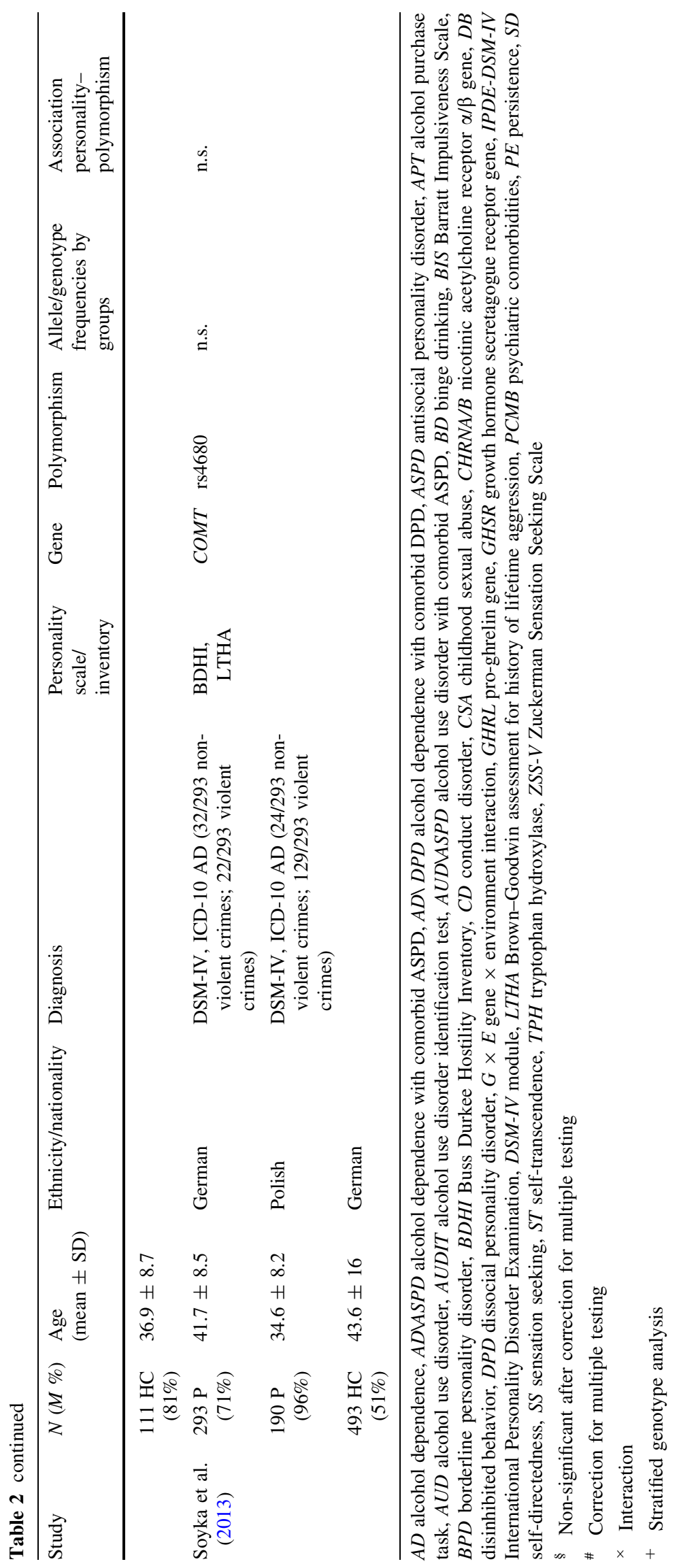


Polymorphic genetic markers used in the studies on AUD

Ten studies investigated polymorphisms in the SLC6A4/ 5HTT gene (Sander et al. 1998; Stoltenberg et al. 2002; Hallikainen et al. 1999; Wiesbeck et al. 2004; Lin et al. 2007; Herman et al. 2011; Koller et al. 2008; Wu et al. 2008; Wang et al. 2013; Matsushita et al. 2001). Most of these studies focused on the 5-HTTLPR functional polymorphism, whereas few considered other polymorphisms such as rs25531, the 17-bp variable tandem repeat in the second intron (STin2 VNTR) and 'novel allelic variants' (XL) (Table 1). Twelve studies focused on dopamine receptors (DRD2 (and ANKK1), DRD3, DRD4) (Sander et al. 1997; Bau et al. 1999, 2000, 2001; Thome et al. 1999; Soyka et al. 2002; Ponce et al. 2003; Lin et al. 2007; Wu et al. 2008), six on serotonin receptors (HTRIA, HTRIB, $H T R 2 A, H T R 3 A, H T R 3 B$ ), four on monoamine oxidase $(M A O-A, M A O B)$ and two on the dopamine transporter (SLC6A3/DAT1). A smaller number of studies assessed polymorphisms in other candidate genes such as $A L D H 2$, CRH1, CHRNA, CHRNB2, CHRNB3, COMT, GHRL, GHSR, PDYN, SLC6A2/NET and TPH (Table 2). One study performed a family-based GWAS analysis, which has been replicated in a population-based GWAS analysis (Wang et al. 2012).

\section{Associations between personality and gene polymorphisms}

The trait of NS usually was associated with the short, and less active, variant of the 5-HTTLPR (Table 1). Specifically, carriers of the s allele showed higher NS scores (Sander et al. 1998; Lin et al. 2007; Wu et al. 2008). Additionally, ADP homozygous for the s allele showed higher risk of Cloninger's Type II alcohol dependence compared to heterozygotes and homozygotes for the 1 allele, as well as healthy controls (Hallikainen et al. 1999). The $s$ allele was associated with a higher load of sociopathy in female ADP patients, whereas the opposite was observed in men (Herman et al. 2011).

With regard to the dopaminergic system (Table 2), the presence of the seven-repeat allele (7R) of the $D R D 4$ exon III $48 \mathrm{bp}$ VNTR polymorphism in ADP was found to be associated with lower HA (Bau et al. 1999), and the DRD 4 7/* genotype interacted with DAT1 10/10 genotype and high NS on alcohol consumption (Bau et al. 2001). Moreover, an association between HA scores and ASPD has been shown in ANKK1 Taq1 A1 ADP carriers (Bau et al. 2000), as well as between ASPD and APD carriers of the A1 allele (Ponce et al. 2003). Additionally, the A1/ $\mathrm{A} 1$ and A1/A2 genotypes were associated with higher NS in a subgroup of ADP with anxiety and depression (Lin et al. 2007). After stratification by 5-HTTLPR genotype, $\mathrm{A} 1 / \mathrm{A} 1$ and A1/A2 genotypes were related to higher NS in ADP with anxiety and depression (Lin et al. 2007), in AD/ ASPD (Wu et al. 2008) and in pure ADP (Wang et al. 2013).

Other investigations had observed a modulatory role of $M A O-A$ polymorphisms on personality and AUD. The MAO-A genotypes have been associated with AD/ASPD (Ducci et al. 2008), and the SNP rs979606 was found to be associated with NS, HA, RD scores in a GWAS (Wang et al. 2012). It should be noted that the sample in the study by Ducci and colleagues is quite specific, including American Indians females who, to a large extent, had been sexually abused during childhood (Ducci et al. 2008). Moreover, the three repeats alleles of the MAO-A VNTR polymorphism, in combination with $A L D H 2 * 1 * 1$, were more frequent in subjects with AD/ASPD (Lee et al. 2009).

Results regarding other polymorphisms in other candidate genes (e.g., tryptophan hydroxylase $T P H$; serotonin receptors HTRIA, HTR1B, HTR2A, HTR3A, HTR3B; monoamine-related enzymes and transporters COMT, DRD3, MAO-A, MAOB, SLC6A2/NET; aldehyde dehydrogenase $A L D H 2$; prodynorphin $P D Y N$; corticotropinreleasing hormone receptor $C R H 1$; cholinergic receptors CHRNB, CHRNA; ghrelin and obestatin prepropeptide GHRL; growth hormone secretagogue receptor GHSR) were sparse. Furthermore, an association between the SNP rs727532 within the ABLIM1 gene and NS, HA and RD in ADP was reported in a family-based GWAS and replicated in a population-based sample of ADP (Wang et al. 2012).

\section{Discussion}

The present review scrutinizes the state of the art on the association between genetics and personality in relation to alcohol dependence. We sought to find evidence of genetically driven personality links to define more homogenous subtypes of AUD. Both candidate gene and genome-wide association studies (GWAS), in which the association between genetic variants and standardized measures of personality among alcohol-dependent patients, were considered. However, the results were sparse and no clear conclusions could be drawn.

\section{Psychobiology of personality}

Traits are usually considered to be the fundamental units of an individual's personality and predispose to a great variety of behaviors. The research area of biological underpinnings of personality traits and personality disorders (PD) has a 
long history (Charney 1999). Several models have been conceptualized, such as the psychodynamic (Freud 2003), humanistic (Rogers and Dymond 1954), learning (Skinner 1950), cognitive (Bandura 1986) and the trait perspective (Allport 2013).

Of relevance to the present study are the "biological approaches", among which Eysenck's (Eysenck and Eysenck 1975), Gray's (Gray 1991) and Cloninger's (Cloninger 1987b) are the most studied. Eysencks threefactor psychometric model was mainly built on Pavlovian learning principles and identified extraversion, neuroticism and psychoticism as the main traits or personality dimensions (Eysenck and Eysenck 1975). A revised version of Eysenck's model is Graýs model, which is based mainly on classical conditioning, but also includes motivational models (motivation and avoidance), impulsivity and anxiety (Gray 1991). These models have been fundamental for the development of Cloninger's model (Cloninger 1987b), an approach to temperament that merges genetic, neurobiological and neuropharmacological data (Allport 2013; Eysenck and Eysenck 1975). In 1987, Cloninger proposed the existence of three personality systems or temperaments and associated them with specific neural systems: HA (anxious, pessimistic vs outgoing, optimistic) that is correlated with high serotonergic levels; NS (impulsive, quick-tempered vs rigid, slow-tempered) characterized by low dopaminergic activity; and RD (warm, approval seeking vs cold, aloof), similar to extraversion, and correlated with low noradrenergic activity (Cloninger 1986, 1987b). According to the Cloninger's psychobiological model, personality dimensions are stable traits already present at early age that have high heritability (temperaments) but are also self-regulated during adulthood by the environment (characters) (Cloninger et al. 1993; Josefsson et al. 2013).

Furthermore, adoption studies performed by Cloninger et al. (1981) provided evidence that those personality traits are efficient in identifying two distinct AUD phenotypes. Type I alcoholism, mainly characterized by binge drinking, loss of control and guilt, and low NS, high HA and RD, and a progressive abuse of alcohol. In contrast, type II is characterized by the inability to abstain from alcohol and seems to be more related to criminal behaviors such as fights and arrests, and conduct disorders. These two types also show opposite characteristics with regard to high NS, and low HA and RD (Cloninger et al. 1996).

Additionally, Babor's studies (Babor et al. 1992) suggested two distinct categories of alcoholics, type A and B. Both Cloninger's type 1 alcoholism and Babor's type A are characterized by late age of onset, weaker family history, lower severity of dependence and less psychiatric and social impairment. Likewise, type 2 and type B are more severe, with earlier onset, stronger family history, more impulsivity and antisocial conduct, and comorbid drug abuse. The major difference is Babor's reliance on self-reported symptoms rather than family history and course of illness in the definition (Babor et al. 1992).

Cloninger's categorization is still used nowadays (Johnson et al. 2000) and more recent studies attempted proving evidence that those traits are distinguishable in patients with AUD and associated with distinct anatomical and functional brain characteristics.

\section{Neurotransmitters, brain, personality and AUD}

Recently, Belcher and colleagues reviewed the literature on the link between substance use disorders (SUD) and personality, brain regions and neurotransmitters proposing that neuro-temperamental associations, represented as three independent variables, could enhance the vulnerability to SUD (Belcher et al. 2014). According to their hypothesis (Belcher et al., 2014), positive emotionality/extraversion (PEM/E), a trait related to Cloninger's NS, is modulated by the dopamine system and its neurocircuitries, involving the substantia nigra, ventral tegmental area, striatum and right cingulate gyrus area. On the other hand, negative emotionality/neuroticism (NEM/N), like Cloninger's HA, is modulated by glutamate and serotonin. It involves the anterior cingulate cortex, ventromedial prefrontal cortex, amygdala and insula, whereas constraint (CON), modulated by glutamate and dopamine, involves the pre-supplementary motor area, right inferior frontal gyrus, striatum and subthalamic nucleus.

Despite that Cloninger's and Belcher's frameworks share some similarities, the involvement of dopamine in NS or PEM/E and of serotonin in HA or NEM/N, they also show some differences. Cloninger expected high levels of dopamine and serotonin in type I (high HA, high RD, low NS) and low levels of serotonin activity in type II (high NS, low HA, low RD) (Cloninger 1987a). In fact, Cloningeŕs type II (high NS, low HA, low RD) would represent a high vulnerability phenotype, while according to Belcher and colleagues it would constitute a resilience factor for SUD (Belcher et al. 2014). This discrepancy can be reconciled by observing that extreme high or extreme low HA increases the risk of type II alcoholism; thus, type II can be considered as a mixture of antisocial individuals, some of whom are low (antisocial or adventurous types) and some high in HA (i.e., borderline or explosive types) (Cloninger et al. 1995, 1988). Alternatively, since Belcher and colleagues find evidences generally on SUD, it could be speculated that their hypothesis may not be specifically valid for alcohol. Furthermore, both type I and type II represent a vulnerability factor model even though type I development of addiction is described as progressive and 
less dramatic compared to type II that seems to lead to a fast shift to addiction (Cloninger et al. 1995).

To date, 38 studies have investigated personality traits, mainly assessed using the Cloninger's TPQ and TCI, in relation with polymorphisms of candidate genes of neurotransmitters systems in alcohol-dependent patients. As summarized in the tables, the analysis on the relation between genotype and personality traits in AUD has highlighted contradictory results, regarding traits, genes and personality.

\section{Serotonin, personality and AUD}

Particular attention was given to the serotonin transporter gene-linked polymorphic region (5-HTTLPR) (Heils et al. 1996). The 5HT gene regulates the expression of the serotonin transporter (named 5-HTT or SERT or SLC6A4) that modulates the termination of the serotonin signal at the synaptic level through a reuptake mechanism (Amara and Kuhar 1993). The 5-HTTLPR consists of an insertion/ deletion of a repeat motif, with each repeat being 22-23 base pair long, occurring in the promoter region of the $5 H T T$ gene. Usually, the two common alleles are referred to as long (l) and short (s), and consist of 14- and 16-repeat alleles, respectively (Nakamura et al. 2000). The functional difference between 1 and $\mathrm{s}$ is a two-/threefold higher transcriptional activity associated with the 1 allele, as assessed in lymphoblast cell lines (Heils et al. 1996; Hahn and Blakely 2007; Lesch and Gutknecht 2005). It has been shown that individuals with the 1 allele have higher levels of 5-HTT in platelets and in the brain ( $\mathrm{Hu}$ et al. 2006). Moreover, one rare variation of this polymorphism has been proved to be functional: an adenine to guanine (A/G) single nucleotide polymorphism (SNP), rs25531, within the 1 allele (Nakamura et al. 2000; Hu et al. 2006; Hahn and Blakely 2007). This SNP was found to modify the transcriptional activity of $5-H T T$, with the $1_{\mathrm{G}}$ allele having equivalent activity to the $\mathrm{s}$ allele, and heterozygotes, $\mathrm{l}_{\mathrm{A}} / \mathrm{l}_{\mathrm{G}}$, $\mathrm{s} / \mathrm{l}$ and $\mathrm{s} / \mathrm{l}_{\mathrm{G}}$, having intermediate activity compared to $\mathrm{s} / \mathrm{s}$ and $1_{\mathrm{A}} / 1_{\mathrm{A}}$ (Hu et al. 2006).

Carrying the $\mathrm{s}$ allele has been associated not only with alcohol dependence (Rubens et al. 2016; Feinn et al. 2005), but also with stress reactivity, impulsivity, anxiety and mood disorders (Reif and Lesch 2003; Walderhaug et al. 2007; Calati et al. 2011; Munafò et al. 2008). The findings of the studies included in the present review cannot support any conclusion regarding the association between 5-HTTLPR and personality traits in relation to alcohol dependence (Table 1). A trend of association was found between NS and homozygosity for the s allele in alcoholdependent individuals with dissocial personality disorder (Sander et al. 1998), anxiety, depression (Lin et al. 2007) and antisocial personality disorder (Wu et al. 2008).
Inversely, a borderline significant association between high levels of HA and heterozygosity has been shown in alcohol-dependent patients with anxiety and depression (Koller et al. 2008; Lin et al. 2007; Wiesbeck et al. 2004). Only one study has found a correlation between homozygosity for the s allele and Cloningeŕs alcoholism type II (Hallikainen et al. 1999). Nevertheless, complementary evidence indeed points to the role of serotonin in the development of AUD.

Personality traits and vulnerability gene variants have a variety of ways to compromise mental health, as etiopathogenetic pathways comprise multiple steps. A pharmacologist would emphasize that AUD quite obviously develops as a consequence of early onset of alcohol use (Liang and Chikritzhs 2015). It is self-evident that personality traits, as well as several of the gene variants, may also exert their effect in the development of AUD via promoting early excessive alcohol use. The 5-HTTLPR genotype has been associated with alcohol use in many studies (Rubens et al. 2016) and, given the evidence of the association between the s allele, neuroticism, higher sensitivity to stress and high reactivity of corpus amygdala in response to aversive stimuli, it is tempting to speculate that the association between the s allele and AUD, if present in a given population, may reflect this aspect of development of the disorder. According to this line of thought, some of the negative findings may well be explained by the existence of highly adaptive behavioral mechanisms that in turn help to understand the persistence of the common "vulnerability variants", otherwise seen as "flexibility variants" (Belsky et al. 2009) in the gene pool. The variable and changeable environmental demands are likely to cause the rather weak, while statistically significant associations between personality and gene variants with alcohol use and the development of AUD. An explanation for that is suggested in a study on two birth cohorts that represent the general population but were collected at different times with several years in between. In both cohorts, alcohol use was more frequent in $\mathrm{s}$ allele carriers of 5-HTTLPR (Merenäkk et al. 2011; Vaht et al. 2014), but this genotype effect appeared at later age in one of the cohorts. Furthermore, a highly significant genotype $\times$ birth cohort interaction effect was found on the age of onset of use of alcohol. While the s/s-homozygote girls were the last group to begin with alcohol in one cohort, they were the earliest, even ahead of boys, in the other birth cohort that grew up when alcohol had become much easier to obtain and more widely used (Vaht et al. 2014). High neuroticism and social desirability, both associated with the $\mathrm{s}$ allele of the 5-HTTLPR, are likely to either suppress or facilitate alcohol use as the societal norms radically change and hence to have the potential to produce opposite effects 
under distinct environmental conditions even within family or community settings.

Through modulation of reward behavioral inhibition and affect, the serotonergic system exerts an important role in addiction (Goodman 2008; Kranz et al. 2010), mainly indirectly through its connections with the dopamine system. Attention has been given to the role of 5-HT1B, 5-HT2A and 5-HT2C receptors in seeking behavior, alcohol consumption and preference in studies of rodents (Pentkowski et al. 2010; Pockros et al. 2011; Czachowski 2005; Furay et al. 2011; Goodman 2008; Rezvani et al. 2014) as well as in humans (Reif and Lesch 2003). In the present review, some studies have investigated the role of HTR $1 B$ and HTR $1 A$ genes, however, without significant results (Sander et al. 2000; Preuss et al. 2001; Koller et al. 2006). On the other hand, studies have shown an association between A/A HTR2A genotype and low levels of behavioral inhibition system trait (Preuss et al. 2001) and between A/A HT3B genotype in alcohol-dependent patients with ASPD (Ducci et al. 2009). Moreover, it has been demonstrated that 5-HT-mediated reduced availability of dopamine enhances seeking behaviors and addiction, in line with low levels of HA and low levels of 5HT, but high levels of NS and low levels of dopamine being associated with Cloningeŕs type II. In the present review, two studies on the DRD2 gene reported a relation between high levels of NS in alcohol-dependent patients carrying the A1 allele, after stratification by 5-HTTLPR genotype (Wu et al. 2008; Wang et al. 2013).

Addiction also shares features with impulse control disorders, characterized by feelings of tension before performing the act, and pleasure and relief once the performance is over (Koob 2011). Personality models depict impulsivity as characterized by various traits such as NS, venturesomeness and sensation seeking, which have been associated with AUD (Stevens et al. 2014). Additionally, a bidirectional interaction between addiction and impulsivity has been reported, with not only increased levels of impulsivity leading to acquire alcohol abuse behavioral patterns, such as seeking and dysregulated intake, but also abuse enhancing impulsivity (Perry and Carroll 2008). High levels of impulsivity have been found in AUD patients (Rogers et al. 2010; Whiteside and Lynam 2003). In line with the hypothesis that serotonin inhibitory control on impulsive behavior is involved in alcohol abuse (Collins and Schlenger 1988), impulsive individuals display lower cerebrospinal fluid levels of the serotonin metabolite 5-HIAA (Goodman 2008; Linnoila et al. 1983).

Serotonin is also involved in the stress system, and compromised stress regulation involves amygdala-mediated effects on the 5-HT pathway projecting from the raphe nuclei to the paraventricular nucleus (Weidenfeld et al.
2002). Though contradictory findings exist, the 5-HTTLPR $\mathrm{s}$ allele has been shown to modulate stress sensitivity, amygdala functioning and its functional connectivity with ACC (Hariri et al. 2002; Canli and Lesch 2007). Increased amygdala activity implies enhanced aversive conditioning to context, and its persistent activation leads to increased negative emotional memories (Pezawas et al. 2005), all well-known processes implied in addiction (Koob 2011). Indeed, enhanced amygdala activity has been proposed as a predictor of drinking behavior (Greenberg et al. 1999) and has been linked with behaviors that are hallmarks of neuroticism, such as fear, worry, depression, stress and anxiety, and that are typically found in alcohol addiction and influence relapse (Koob 2011). Reduced fronto-amygdalar connectivity has been shown in the presence of neuroticism in healthy subjects (Kennis et al. 2013) and AUD patients (Belcher et al. 2014). It is thus plausible that high levels of serotonin and enhanced amygdala activity are the biological substrate of HA that represents a susceptibility endophenotype of AUD (Belcher et al. 2014). However, the literature on alcohol as an outcome of the interaction between 5-HTTLPR and stress is discordant both in human and non-human primates (reviewed by Todkar et al. (2013).

\section{Dopamine, noradrenaline, personality and AUD}

The dopaminergic system exerts a major role in addiction, regulating reward prediction, incentive salience and motivated behavior, as well as impulsivity and mood (Koob 2011). Indeed, postsynaptic D1 and D5 receptors have a role in motivation processes, and presynaptic receptors D2, D3, D4 in behavioral inhibition (Goodman 2008). Particular attention has been given to the TaqI polymorphism on the $A N K K 1$ gene. Patients carrying the A1 allele show low striatal levels of D2 receptors, associated with seeking for reinforcers and alcohol consumption (Comings and Blum 2000). In addition, association have been found between DRD2 and DRD4 polymorphisms and novelty seeking, substance abuse and impulsivity behavior (Belcher et al. 2014; Ebstein et al. 1996; Noble et al. 1998; Lee et al. 2003a), as well as schizophrenia and mood disorders (Blum et al. 1996). Nevertheless, in the present review, studies of polymorphisms on the DRD2 and DRD4 genes yield inconsistent results. Furthermore, noradrenaline regulates the stress system release and increases during withdrawal. Among the reviewed studies, one study on the noradrenaline transporter gene (NET) found an association between the rs5569 polymorphism of the gene and reward dependence personality trait in alcoholics (Samochowiec et al. 2002). Future studies should also investigate polymorphisms of systems such as the GABAergic and glutamatergic, which play an important role in AUD. 


\section{Confounding factors}

Several covariates such as comorbidity, gene-environment interactions, sex and ethnicity need to be considered. As summarized in the tables, comorbidity between AUD and depression and anxiety disorders is common, and shared genetic vulnerability is plausible (Cross-Disorder Group of the Psychiatric Genomics 2013). Despite the discordance and sparse nature of findings of the herein reviewed studies, it is obvious that a great number of genes should be involved in AUD, with likely different genes being of greater importance at various stages of addiction (Koob and Volkow 2010), and that genetic and neural underpinnings of personality traits contribute not only to AUD but also to other psychiatric phenotypic conditions. In fact, a recent genome-wide meta-analysis has shown a relation between genetic loci, personality traits and psychiatric conditions (Lo et al. 2016). Furthermore, overlapping genetic constructs across psychiatric disorders are beginning to be demonstrated (Lee et al. 2013; Smoller et al. 2013). Additionally, psychiatric conditions, as presently defined, have been associated with both the higher or lower end of a personality trait, thus making the neurobiology dissection of AUD and comorbid disorders difficult. For instance, low $M A O-A$ expression genotype has been linked to AUD-related behaviors such as high impulsivity, aggression and violence, while the high activity MAO-A genotype has been associated with anxiety and depression (Naoi et al. 2016). Thus, both gene variants seem to constitute vulnerability factors, although the underlying developmental trajectories would probably reflect two different subtypes of AUD.

It must also be taken into account that various personality-linked types of AUD are influenced by genes and environment interacting with each other and that those two factors influence each other in a way that is yet difficult to understand. Epigenetics is likely to be the molecular missing link behind this interaction (Shukla et al. 2008). Epigenetics refers to processes that influence the regulation of DNA transcription without changing the original sequence itself. Epigenetic marks (e.g., DNA methylation), which are experience dependent (e.g., early life stress) as well as influenced by genetic architecture, can leave longlasting changes at the neurobiological and behavioral levels. Accordingly, Philibert and colleagues found that MAO-A gene methylation is not associated with antisocial personality disorder but with AUD in women, and in a MAO-A genotype-dependent manner (Philibert et al. 2008). However, genetic associations with personality profiles and AUD should also consider differential susceptibility of specific candidate genes operating in both adverse and beneficial contexts, which results in extraordinarily poor or remarkably positive phenotypes in certain subpopulations as a consequence of psychosocial and physical environmental conditions (Boyce 2016). Recently, it has been shown that individuals carrying combinations of susceptible variants of the $B D N F, 5-H T T$ and MAO-A genes are less delinquent when controlling for the interaction of positive parent-child relationship (Nilsson et al. 2014). On the other hand, functionally opposite genotypic combinations are associated with delinquent behavior in the presence of maltreatment and sexual abuse, and the experience of a positive environment modulates the experience of a bad environment in an $\mathrm{E} \times \mathrm{E}$ interaction manner on top of the $\mathrm{G} \times \mathrm{E}$ interaction (Nilsson et al. 2014). Furthermore, it can be suggested that genetic associations of clinical casecontrol studies mimic $\mathrm{G} \times \mathrm{E}$ studies, since the patients most often have been more exposed to negative life events associated with the phenotype of interest. Therefore, clinical subpopulations displaying AUD with an antisocial component could be very much different in their genetic and environmental makeup than another subpopulation with AUD and anxiety traits, and respond differently to treatment (Karno and Longabaugh 2004). This implies that the individual characteristics may better fit with some environments than with others, and hereditary capacities may only become manifest in challenging or responsive environments (Reiss et al. 2013).

Concerning personality, although character traits are as heritable as temperament (Gillespie et al. 2003), character traits have been shown to be more influenced by sociocultural influences than temperament (Cloninger et al. 1993; Cloninger 1987b; Josefsson et al. 2013). A recent study on adolescents has suggested that personality traits may play a role in driving the individual to the initial use of alcohol as well as choosing between different environments (Heinrich et al. 2016). Early environmental experiences, like traumatic events during childhood, have been associated with high vulnerability to AUD (De Bellis 2002). Recently, a multidisciplinary study systematically examined several components of alcohol misuse in adolescents, such as environmental factors, personality, candidate genes, brain structure and functionality. It was reported that NS was strongly associated with personal life events and binge drinking behaviors, while consciousness was lower in current and future binge adolescents (Whelan et al. 2014). A more recent longitudinal study showed that the adolescents homozygous for the A allele of the vesicular monoamine transporter (VMAT1) showed low levels of neuroticism, anxiety and impulsivity, but also were less likely to be diagnosed with alcohol dependence in the following 5 years, suggesting that the gene has a role in resiliency to negative emotions (Vaht et al. 2016). Coping, a common reason for drinking (Comasco et al. 2010), has indeed been found to mediate the relation between AUD and certain personality traits, thus playing a critical role in 
vulnerability to AUD (Cooper et al. 2000; Kuntsche et al. 2006; Tragesser et al. 2007). Furthermore, life events, such as physical or sexual abuse in adolescence, stress and opportunity to drink, can facilitate the expression of a silent genetic susceptibility (Nestler 2000). Serotonin is a neurotransmitter involved in brain development, from neurogenesis to neuronal differentiation in early life, and in the maintenance and plasticity of the brain in adulthood (Cases et al. 1996; Gaspar et al. 2003; Nordquist and Oreland 2010); thus, prenatal exposure and early life events such as traumatic experiences or early approaches to alcohol may interfere with those processes.

Regarding sex differences, recent evidences show that sex plays a role in alcohol consumption and addiction (Sanchis-Segura and Becker 2016). In fact, the heritability of AUD is higher in males than in females (Khemiri et al. 2016; Prescott 2002) and men display higher alcohol consumption and more than a double prevalence of lifetime alcohol dependence compared to women, who on the other hand are more likely to display more negative physical and mental health outcomes due to AUD than men (NolenHoeksema 2004). Furthermore, Cloninger's alcoholic subtypes have shown different personality trait differences related to sex, with type II primarily found in males (Knorring and Oreland 1996). Additionally, while women score higher on RD and HA than men (Miettunen et al. 2007), men score higher on sensation seeking (Cross et al. 2013), and while women have higher scores on neuroticism, men tend to have higher scores on psychoticism (Weijers et al. 2003). Accordingly, a recent study has found high levels of neuroticism and anxiety in women and high levels of NS to be related to binge drinking behaviors in university students (Adan et al. 2016). Those evidences highlight the fact that traits may predispose to AUD in a sex-dependent manner. Further investigations should be performed to study brain development and hormonal variations that could play a role at different ages (Toffoletto et al. 2014; Sanchis-Segura and Becker 2016). In the present review, as also pointed out by other authors (NolenHoeksema 2004), most studies neglected possible sex effects by assessing all-male samples, and, in case that both sexes were considered, the female samples were much smaller. In addition, it has recently been proposed that the 5-HTTLPR gene may influence 5-HTT expression according to sex, due to the evidence that the gene affects 5-HT functioning in different ways among men and women in the development of depression or affective dysregulation (Gressier et al. 2016; Sjöberg et al. 2006; Brummett et al. 2008). In fact, while cultural-driven gender differences can change, biological sex differences remain, but are often neglected.

Lastly, another explanation about the inconsistencies of the data could be due to ethnicity-based differences in genotype frequencies (Pascale 2015). With regard to ethnicity-based differences in the frequency of alleles of the 5-HTTLPR (Hahn and Blakely 2007; Edenberg et al. 1998; Gelernter et al. 1997), the 1 allele is less frequent in Asian compared to European-American populations (Lee et al. 2003b; Nakamura et al. 2000), while the s allele frequency has been found to be low in African Americans (0.25), intermediate in Caucasians of American and Finnish origin (0.35-0.40) and high in American Indians (0.64-0.66). Furthermore, the $1_{\mathrm{G}}$ was almost absent in two populations of American Indians ( $\mathrm{Hu}$ et al. 2006).

\section{Future perspectives and conclusions}

AUD is a biopsychosocial phenomenon influenced by several variables, e.g., genes, personality, environmental events, brain structure, emotion and cognitive functioning, socio-demographic factors, age and sex. In fact, while there is a large agreement that the genetic makeup plays an important role on the risk of AUD, an assumption mainly based on twin and family studies (Goldman et al. 2005), neither candidate gene approaches nor GWAS have substantially advanced knowledge. On the other hand, studies investigating the genetic contribution to a phenotype, by comparing shared and non-shared environment, did not consider gene-environment interactions (Munafo et al. 2014). In addition, the complexity of the relations between genes and personality is worsened by non-linear dynamic relations. In fact, geneticists have introduced the concepts of "multifinality" and "equifinality" to describe that either the same or different genetic networks may lead to, respectively, different or similar behaviors involved in complex disorders (Arnedo et al. 2015).

Future studies should therefore control for well-known confounding variables such as sex, parental and personal history of the participants, socio-demographic factors, stressful life events and comorbid symptoms. Ideally, validated methodologies and structured interviews aiming at in-depth phenotyping could help to define the grade in which behavior and biology are connected, most likely closer to the research domain criteria than to nosological constructs such as the DSM criteria and categories. Despite practical limitations, longitudinal studies comprising larger but also more homogenous samples would additionally allow performing within-subject statistics that could help clarify dynamic trajectories toward AUD and whole-genome-based analyses. Only one GWAS study has been performed to date; the strongest association reported was between the Actin Binding LIM Protein 1 (ABLIMI) gene and NS, HA and RD in AUD patients (Wang et al. 2012). However, the role of this gene in AUD remains to be explored. Finally, it is equally important to investigate resilient personality dimensions, their relation with reasons 
for not drinking, and genetic and environmental correlates (Feder et al. 2009).

In conclusion, evidence from family and twin studies supports a genetic basis for AUD, but the clinical heterogeneity among AUD patients has made research on risk and resilience factors difficult. This can be easily understood when considering that AUD can be a consequence of an impulsive, sensation-seeking and extroverted personality, as well as of an anxiety-prone and introverted personality, which by several neurobiological markers might represent two different extremes with regard to personality. This complexity of AUD is reflected in many efforts through the years to construct psycho-biological models to classify clinically relevant AUD subtypes to improve the clinical management. Personality is strongly regulated by genetic factors and should therefore be a top candidate intermediate correlate for the dissection of the genetic underpinnings of different subtypes of AUD (Fig. 1).

Acknowledgements The following funding sources are acknowledged: Alcohol Research Council of the Swedish Alcohol Retailing Monopoly, Fredrik and Ingrid Thuring Foundation, Lars Hierta's Minne Foundation, Swedish Brain Foundation, Lundberg's and Karlsson's Foundation and Ankarstrand's Foundation, the Swedish Council for Working Life and Social Research, the Uppsala and Örebro Regional Research Council, the County Council of Västmanland, the König-Söderströmska Foundation, the Svenska Spel Research Foundation, Bertil Hållsten's Research Fund and EMES grant IUT20-40. E.C. is a Marie Skłodowska Curie fellow and received funds from the Swedish Research Council (VR: 2015-00495) and EU FP7-People-Cofund (INCA 600398).

\section{Compliance with ethical standards}

\section{Conflict of interest None.}

Open Access This article is distributed under the terms of the Creative Commons Attribution 4.0 International License (http://crea tivecommons.org/licenses/by/4.0/), which permits unrestricted use, distribution, and reproduction in any medium, provided you give appropriate credit to the original author(s) and the source, provide a link to the Creative Commons license, and indicate if changes were made.

\section{References}

Adan A, Navarro JF, Forero DA (2016) Personality profile of binge drinking in university students is modulated by sex. A study using the alternative five factor model. Drug Alcohol Depend 165:120-125

Allport G (2013) Personality: a psychological interpretation. 1937. Henry Holt, New York

Almasy L (2003) Quantitative risk factors as indices of alcoholism susceptibility. Ann Med 35(5):337-343

Amara SG, Kuhar MJ (1993) Neurotransmitter transporters: recent progress. Annu Rev Neurosci 16:73-93

Anghelescu I, Klawe C, Fehr C, Singer P, Schleicher A, Himmerich H, Hiemke C, Dahmen N, Szegedi A (2005) The TPH intron 7 A218C polymorphism and TCI dimension scores in alcohol- dependent patients: hints to nonspecific psychopathology. Addict Behav 30(6):1135-1143. doi:10.1016/j.addbeh.2004.11.002

Anghelescu I, Klawe C, Singer P, Fehr C, Hiemke C, Quante A, Regen F, Dahmen N, Szegedi A (2010) Low novelty seeking and high self directedness scores in alcohol-dependent patients without comorbid psychiatric disorders homozygous for the A10 allele of the dopamine transporter gene. World J Biol Psychiatry Off J World Fed Soc Biol Psychiatry 11(2 Pt 2):382-389. doi:10.1080/15622970701775058

Arnedo J, Svrakic DM, Del Val C, Romero-Zaliz R, HernándezCuervo H, Fanous AH, Pato MT, Pato CN, de Erausquin GA, Cloninger CR (2015) Molecular Genetics of Schizophrenia Consortium. Uncovering the hidden risk architecture of the schizophrenias: confirmation in three independent genome-wide association studies. Am J Psychiatry 172:139-153

Babor TF, Hofmann M, DelBoca FK, Hesselbrock V, Meyer RE, Dolinsky ZS, Rounsaville B (1992) Types of alcoholics, I: evidence for an empirically derived typology based on indicators of vulnerability and severity. Arch Gen Psychiat 49(8):599-608

Baingana F, Al'Absi M, Becker AE, Pringle B (2015) Global research challenges and opportunities for mental health and substance-use disorders. Nature 527(7578):S172-S177

Balthazart J, Baillien M, Cornil CA, Ball GF (2004) Preoptic aromatase modulates male sexual behavior: slow and fast mechanisms of action. Physiol Behav 83(2):247-270

Bandura A (1986) Social foundations of thought and action: a social cognitive theory. Prentice-Hall Inc, USA

Bau CH, Roman T, Almeida S, Hutz MH (1999) Dopamine D4 receptor gene and personality dimensions in Brazilian male alcoholics. Psychiatr Genet 9(3):139-143

Bau CH, Almeida S, Hutz MH (2000) The TaqI A1 allele of the dopamine D2 receptor gene and alcoholism in Brazil: association and interaction with stress and harm avoidance on severity prediction. Am J Med Genet 96(3):302-306

Bau CH, Almeida S, Costa FT, Garcia CE, Elias EP, Ponso AC, Spode A, Hutz MH (2001) DRD4 and DAT1 as modifying genes in alcoholism: interaction with novelty seeking on level of alcohol consumption. Mol Psychiatry 6(1):7-9

Belcher AM, Volkow ND, Moeller FG, Ferré S (2014) Personality traits and vulnerability or resilience to substance use disorders. Trends in cognitive sciences 18(4):211-217

Belsky J, Jonassaint C, Pluess M, Stanton M, Brummett B, Williams R (2009) Vulnerability genes or plasticity genes\&quest. Mol psychiatry 14(8):746-754

Blum K, Braverman ER, Wood RC, Gill J, Li C, Chen TJ, Taub M, Montgomery AR, Sheridan PJ, Cull JG (1996) Increased prevalence of the Taq I Alallele of the dopamine receptor gene (DRD2) in obesity with comorbid substance use disorder: a preliminary report. Pharmacogen Genom 6(4):297-305

Boyce WT (2016) Differential susceptibility of the developing brain to contextual adversity and stress. Neuropsychopharmacology 41(1):142-162

Brummett BH, Boyle SH, Siegler IC, Kuhn CM, Ashley-Koch A, Jonassaint CR, Züchner S, Collins A, Williams RB (2008) Effects of environmental stress and gender on associations among symptoms of depression and the serotonin transporter gene linked polymorphic region (5-HTTLPR). Behav Genet 38(1):34-43

Buss AH, Durkee A (1957) An inventory for assessing different kinds of hostility. J Consult Psychol 21(4):343

Calati R, De Ronchi D, Bellini M, Serretti A (2011) The 5-HTTLPR polymorphism and eating disorders: a meta-analysis. Int $\mathrm{J}$ Eat Disord 44(3): 191-199

Canli T, Lesch K-P (2007) Long story short: the serotonin transporter in emotion regulation and social cognition. Nat Neurosci 10(9):1103-1109 
Cardoso JM, Barbosa A, Ismail F, Pombo S (2006) NETER alcoholic typology (NAT). Alcohol Alcohol 41(2):133-139

Cases O, Vitalis T, Seif I, De Maeyer E, Sotelo C, Gaspar P (1996) Lack of barrels in the somatosensory cortex of monoamine oxidase A-deficient mice: role of a serotonin excess during the critical period. Neuron 16(2):297-307

Charney DS (1999) Neurobiology of mental illness. Oxford University Press, New York

Cloninger CR (1986) A unified biosocial theory of personality and its role in the development of anxiety states. Psychiatr Dev $3(2): 167-226$

Cloninger C (1987a) Neurogenetic adaptive mechanisms. Science 236:410-416

Cloninger CR (1987b) A systematic method for clinical description and classification of personality variants - a proposal. Arch Gen Psychiat 44(6):573-588

Cloninger CR, Bohman M, Sigvardsson S (1981) Inheritance of alcohol abuse. Cross-fostering analysis of adopted men. Arch Gen Psychiatry 38(8):861-868

Cloninger CR, Sigvardsson S, Bohman M (1988) Childhood personality predicts alcohol abuse in young adults. Alcohol Clin Exp Res 12(4):494-505

Cloninger CR, Przybeck TR, Svrakic DM (1991) The tridimensional personality questionnaire: US normative data. Psychol Rep 69(3):1047-1057

Cloninger CR, Svrakic DM, Przybeck TR (1993) A psychobiological model of temperament and character. Arch Gen Psychiatry 50(12):975-990

Cloninger CR, Przybeck TR, Svrakic DM (1994) The Temperament and Character Inventory (TCI): A guide to its development and use. Center for Psychobiology of Personality, Washington University, St. Louis

Cloninger CR, Sigvardsson S, Przybeck TR, Svrakic DM (1995) Personality antecedents of alcoholism in a national area probability sample. Eur Arch Psychiatry Clin Neurosci 245(4-5):239-244

Cloninger CR, Sigvardsson S, Bohman M (1996) Type I and type II alcoholism: an update. Alcohol Res Health 20(1):18

Collins JJ, Schlenger WE (1988) Acute and chronic effects of alcohol use on violence. J Stud Alcohol 49(6):516-521

Comasco E, Berglund K, Oreland L, Nilsson KW (2010) Why do adolescents drink? Motivational patterns related to alcohol consumption and alcohol-related problems. Subst Use Misuse 45(10): 1589-1604

Comings DE, Blum K (2000) Reward deficiency syndrome: genetic aspects of behavioral disorders. Prog Brain Res 126:325-341

Cooper ML, Agocha VB, Sheldon MS (2000) A motivational perspective on risky behaviors: the role of personality and affect regulatory processes. J Pers 68(6):1059-1088

Cross CP, Cyrenne DL, Brown GR (2013) Sex differences in sensation-seeking: a meta-analysis. Sci Rep 3:2486

Cross-Disorder Group of the Psychiatric Genomics C (2013) Identification of risk loci with shared effects on five major psychiatric disorders: a genome-wide analysis. Lancet 381(9875):1371-1379

Czachowski CL (2005) Manipulations of serotonin function in the nucleus accumbens core produce differential effects on ethanol and sucrose seeking and intake. Alcohol Clin Exp Res 29(7):1146-1155

De Bellis MD (2002) Developmental traumatology: a contributory mechanism for alcohol and substance use disorders. Psychoneuroendocrinology 27(1):155-170

Ducci F, Enoch MA, Hodgkinson C, Xu K, Catena M, Robin RW, Goldman D (2008) Interaction between a functional MAOA locus and childhood sexual abuse predicts alcoholism and antisocial personality disorder in adult women. Mol Psychiatry 13(3):334-347. doi:10.1038/sj.mp.4002034

Ducci F, Enoch MA, Yuan Q, Shen PH, White KV, Hodgkinson C, Albaugh B, Virkkunen M, Goldman D (2009) HTR3B is associated with alcoholism with antisocial behavior and alpha EEG power-an intermediate phenotype for alcoholism and comorbid behaviors. Alcohol (Fayetteville, NY) 43(1):73-84

Ebstein RP, Novick O, Umansky R, Priel B, Osher Y, Blaine D, Bennett ER, Nemanov L, Katz M, Belmaker RH (1996) Dopamine D4 receptor (D4DR) exon III polymorphism associated with the human personality trait of novelty seeking. Nat Genet 12(1):78-80

Edenberg HJ, Reynolds J, Koller DL, Begleiter H, Bucholz KK, Conneally PM, Crowe R, Goate A, Hesselbrock V, Li TK, Nurnberger JI, Porjesz B, Reich T, Rice JP, Schuckit M, Tischfield JA, Foroud T (1998) A family-based analysis of whether the functional promoter alleles of the serotonin transporter gene HTT affect the risk for alcohol dependence. Alcohol Clin Exp Res 22(5):1080-1085

Eysenck HJ, Eysenck SBG (1975) Manual of the Eysenck Personality Questionnaire (junior and adult). Hodder and Stoughton, London

Feder A, Nestler EJ, Charney DS (2009) Psychobiology and molecular genetics of resilience. Nat Rev Neurosci 10(6):446-457

Feinn R, Nellissery M, Kranzler HR (2005) Meta-analysis of the association of a functional serotonin transporter promoter polymorphism with alcohol dependence. Am J Med Genet Part B Neuropsychiatr Genet 133(1):79-84

Flory JD, Pytte CL, Hurd Y, Ferrell RE, Manuck SB (2011) Alcohol dependence, disinhibited behavior and variation in the prodynorphin gene. Biol Psychol 88(1):51-56. doi:10.1016/j. biopsycho.2011.06.007

Franck J, Jayaram-Lindström N (2013) Pharmacotherapy for alcohol dependence: status of current treatments. Curr Opin Neurobiol 23(4):692-699

Freud S (2003) Beyond the pleasure principle, vol 840, Penguin, UK

Furay AR, Neumaier JF, Mullenix AT, Kaiyala KK, Sandygren NK, Hoplight BJ (2011) Overexpression of 5-HT 1B mRNA in nucleus accumbens shell projection neurons differentially affects microarchitecture of initiation and maintenance of ethanol consumption. Alcohol (Fayetteville, NY) 45(1):19-32

Gaspar P, Cases O, Maroteaux L (2003) The developmental role of serotonin: news from mouse molecular genetics. Nat Rev Neurosci 4(12):1002-1012

Gelernter J, Kranzler H, Cubells JF (1997) Serotonin transporter protein (SLC6A4) allele and haplotype frequencies and linkage disequilibria in African- and European-American and Japanese populations and in alcohol-dependent subjects. Hum Genet 101(2):243-246

Gillespie NA, Cloninger CR, Heath AC, Martin NG (2003) The genetic and environmental relationship between Cloninger's dimensions of temperament and character. Personal Individ Differ 35(8):1931-1946

Goldman D, Oroszi G, Ducci F (2005) The genetics of addictions: uncovering the genes. Nat Rev Genet 6(7):521-532

Goodman A (2008) Neurobiology of addiction. An integrative review. Biochem Pharmacol 75(1):266-322

Gray JA (1991) Neural systems, emotion and personality. Neurobiol Learn Emot Affect 4:273-396

Greenberg PE, Sisitsky T, Kessler RC, Finkelstein SN, Berndt ER, Davidson JR, Fyer AJ (1999) The economic burden of anxiety disorders in the 1990s. J Clin Psychiatry 60(7):427-435

Gressier F, Calati R, Serretti A (2016) 5-HTTLPR and gender differences in affective disorders: a systematic review. J Affect Disord 190:193-207 
Grucza RA, Robert Cloninger C, Bucholz KK, Constantino JN, Schuckit MI, Dick DM, Bierut LJ (2006) Novelty seeking as a moderator of familial risk for alcohol dependence. Alcohol Clin Exp Res 30(7):1176-1183

Hahn MK, Blakely RD (2007) The functional impact of SLC6 transporter genetic variation. Annu Rev Pharmacol Toxicol 47:401-441

Hallikainen T, Saito T, Lachman HM, Volavka J, Pohjalainen T, Ryynanen OP, Kauhanen J, Syvalahti E, Hietala J, Tiihonen J (1999) Association between low activity serotonin transporter promoter genotype and early onset alcoholism with habitual impulsive violent behavior. Mol Psychiatry 4(4):385-388

Hariri AR, Mattay VS, Tessitore A, Kolachana B, Fera F, Goldman D, Egan MF, Weinberger DR (2002) Serotonin transporter genetic variation and the response of the human amygdala. Science 297(5580):400-403

Heils A, Teufel A, Petri S, Stober G, Riederer P, Bengel D, Lesch KP (1996) Allelic variation of human serotonin transporter gene expression. J Neurochem 66(6):2621-2624

Heinrich A, Müller KU, Banaschewski T, Barker GJ, Bokde AL, Bromberg U, Büchel C, Conrod P, Fauth-Bühler M, Papadopoulos D (2016) Prediction of alcohol drinking in adolescents: personality-traits, behavior, brain responses, and genetic variations in the context of reward sensitivity. Biol Psychol 118:79-87

Herman AI, Conner TS, Anton RF, Gelernter J, Kranzler HR, Covault $\mathbf{J}$ (2011) Variation in the gene encoding the serotonin transporter is associated with a measure of sociopathy in alcoholics. Addict Biol 16(1):124-132

Hines LM, Ray L, Hutchison K, Tabakoff B (2005) Alcoholism: the dissection for endophenotypes. Dialogues Clin Neurosci 7(2):153-163

Hu XZ, Lipsky RH, Zhu G, Akhtar LA, Taubman J, Greenberg BD, $\mathrm{Xu} \mathrm{K}$, Arnold PD, Richter MA, Kennedy JL, Murphy DL, Goldman D (2006) Serotonin transporter promoter gain-offunction genotypes are linked to obsessive-compulsive disorder. Am J Hum Genet 78(5):815-826

Johnson BA, Cloninger CR, Roache JD, Bordnick PS, Ruiz P (2000) Age of onset as a discriminator between alcoholic subtypes in a treatment-seeking outpatient population. Am $\mathrm{J}$ Addict 9(1):17-27

Josefsson K, Jokela M, Cloninger CR, Hintsanen M, Salo J, Hintsa T, Pulkki-Råback L, Keltikangas-Järvinen L (2013) Maturity and change in personality: developmental trends of temperament and character in adulthood. Dev Psychopathol 25(03):713-727

Karno MP, Longabaugh R (2004) What do we know? Process analysis and the search for a better understanding of Project MATCH's anger-by-treatment matching effect. J Stud Alcohol 65(4):501-512

Kennis M, Rademaker AR, Geuze E (2013) Neural correlates of personality: an integrative review. Neurosci Biobehav Rev 37(1):73-95

Khemiri L, Kuja-Halkola R, Larsson H, Jayaram-Lindström N (2016) Genetic overlap between impulsivity and alcohol dependence: a large-scale national twin study. Psychol Med 46(05):1091-1102

Kimura M, Sawayama T, Matsushita S, Higuchi S, Kashima H (2009) Association between personality traits and ALDH2 polymorphism in Japanese male alcoholics. Alcohol Clin Exp Res 33(5):799-803. doi:10.1111/j.1530-0277.2009.00898.x

Knorring L, Oreland L (1996) Platelet MAO activity in type 1/type 2 alcoholics. Alcohol Clin Exp Res 20(s8):224a-230a

Knorring AL, Bohman M, Lv Knorring, Oreland L (1985) Platelet MAO activity as a biological marker in subgroups of alcoholism. Acta Psychiatr Scand 72(1):51-58

Koller G, Bondy B, Preuss UW, Bottlender M, Soyka M (2003) No association between a polymorphism in the promoter region of the MAOA gene with antisocial personality traits in alcoholics. Alcohol Alcohol 38(1):31-34

Koller G, Bondy B, Preuss UW, Zill P, Soyka M (2006) The C(1019)G 5-HT1A promoter polymorphism and personality traits: no evidence for significant association in alcoholic patients. Behav Brain Funct BBF 2:7. doi:10.1186/1744-9081-2-7

Koller G, Zill P, Skoruppa T, Bondy B, Preuss UW, Soyka M (2008) Low level of harm avoidance is associated with serotonin transporter functional haplotype in alcohol-dependent individuals. Psychiatr Genet 18(2):59-63. doi:10.1097/YPG. 0b013e $3282 \mathrm{f} 60333$

Koob GF (2011) Neurobiology of addiction. Focus 9(1):55-65

Koob GF, Volkow ND (2010) Neurocircuitry of addiction. Neuropsychopharmacology 35(1):217-238

Kranz GS, Kasper S, Lanzenberger R (2010) Reward and the serotonergic system. Neuroscience 166(4):1023-1035

Kuntsche E, Knibbe R, Gmel G, Engels R (2006) Who drinks and why? A review of socio-demographic, personality, and contextual issues behind the drinking motives in young people. Addict Behav 31(10):1844-1857

Landgren S, Berglund K, Jerlhag E, Fahlke C, Balldin J, Berggren U, Zetterberg H, Blennow K, Engel JA (2011) Reward-related genes and personality traits in alcohol-dependent individuals: a pilot case control study. Neuropsychobiology 64(1):38-46. doi:10.1159/000324992

Lee HJ, Lee HS, Kim YK, Kim L, Lee MS, Jung IK, Suh KY, Kim S (2003a) D2 and D4 dopamine receptor gene polymorphisms and personality traits in a young Korean population. Am J Med Genet Part B Neuropsychiatr Genet 121(1):44-49

Lee JH, Kim HT, Hyun DS (2003b) Possible association between serotonin transporter promoter region polymorphism and impulsivity in Koreans. Psychiatry Res 118(1):19-24

Lee SY, Hahn CY, Lee JF, Chen SL, Chen SH, Yeh TL, Kuo PH, Lee IH, Yang YK, Huang SY, Ko HC, Lu RB (2009) MAOAuVNTR polymorphism may modify the protective effect of ALDH2 gene against alcohol dependence in antisocial personality disorder. Alcohol Clin Exp Res 33(6):985-990

Lee SH, Ripke S, Neale BM, Faraone SV, Purcell SM, Perlis RH, Mowry BJ, Thapar A, Goddard ME, Witte JS, Absher D, Agartz I, Akil H, Amin F, Andreassen OA, Anjorin A, Anney R, Anttila V, Arking DE, Asherson P, Azevedo MH, Backlund L, Badner JA, Bailey AJ, Banaschewski T, Barchas JD, Barnes MR, Barrett TB, Bass N, Battaglia A, Bauer M, Bayes M, Bellivier F, Bergen SE, Berrettini W, Betancur C, Bettecken T, Biederman J, Binder EB, Black DW, Blackwood DHR, Bloss CS, Boehnke M, Boomsma DI, Breen G, Breuer R, Bruggeman R, Cormican P, Buccola NG, Buitelaar JK, Bunney WE, Buxbaum JD, Byerley WF, Byrne EM, Caesar S, Cahn W, Cantor RM, Casas M, Chakravarti A, Chambert K, Choudhury K, Cichon S, Cloninger CR, Collier DA, Cook EH, Coon H, Cormand B, Corvin A, Coryell WH, Craig DW, Craig IW, Crosbie J, Cuccaro ML, Curtis D, Czamara D, Datta S, Dawson G, Day R, De Geus EJ, Degenhardt F, Djurovic S, Donohoe GJ, Doyle AE, Duan JB, Dudbridge F, Duketis E, Ebstein RP, Edenberg HJ, Elia J, Ennis $\mathrm{S}$, Etain B, Fanous A, Farmer AE, Ferrier IN, Flickinger M, Fombonne E, Foroud T, Frank J, Franke B, Fraser C, Freedman R, Freimer NB, Freitag CM, Friedl M, Frisen L, Gallagher L, Gejman PV, Georgieva L, Gershon ES, Geschwind DH, Giegling I, Gill M, Gordon SD, Gordon-Smith K, Green EK, Greenwood TA, Grice DE, Gross M, Grozeva D, Guan WH, Gurling H, De Haan L, Haines JL, Hakonarson H, Hallmayer J, Hamilton SP, Hamshere ML, Hansen TF, Hartmann AM, Hautzinger M, Heath AC, Henders AK, Herms S, Hickie IB, Hipolito M, Hoefels S, Holmans PA, Holsboer F, Hoogendijk WJ, Hottenga JJ, Hultman CM, Hus V, Ingason A, Ising M, Jamain S, Jones EG, Jones I, Jones L, Tzeng JY, Kahler AK, 
Kahn RS, Kandaswamy R, Keller MC, Kennedy JL, Kenny E, Kent L, Kim Y, Kirov GK, Klauck SM, Klei L, Knowles JA, Kohli MA, Koller DL, Konte B, Korszun A, Krabbendam L, Krasucki R, Kuntsi J, Kwan P, Landen M, Langstrom N, Lathrop M, Lawrence J, Lawson WB, Leboyer M, Ledbetter DH, Lee $\mathrm{PH}$, Lencz T, Lesch KP, Levinson DF, Lewis CM, Li J, Lichtenstein P, Lieberman JA, Lin DY, Linszen DH, Liu CY, Lohoff FW, Loo SK, Lord C, Lowe JK, Lucae S, MacIntyre DJ, Madden PAF, Maestrini E, Magnusson PKE, Mahon PB, Maier W, Malhotra AK, Mane SM, Martin CL, Martin NG, Mattheisen M, Matthews K, Mattingsdal M, McCarroll SA, McGhee KA, McGough JJ, McGrath PJ, McGuffin P, McInnis MG, McIntosh A, McKinney R, McLean AW, McMahon FJ, McMahon WM, McQuillin A, Medeiros H, Medland SE, Meier S, Melle I, Meng F, Meyer J, Middeldorp CM, Middleton L, Milanova V, Miranda A, Monaco AP, Montgomery GW, Moran JL, Moreno-De-Luca D, Morken G, Morris DW, Morrow EM, Moskvina V, Muglia P, Muhleisen TW, Muir WJ, Muller-Myhsok B, Murtha M, Myers RM, Myin-Germeys I, Neale MC, Nelson SF, Nievergelt CM, Nikolov I, Nimgaonkar V, Nolen WA, Nothen MM, Nurnberger JI, Nwulia EA, Nyholt DR, O'Dushlaine C, Oades RD, Olincy A, Oliveira G, Olsen L, Ophoff RA, Osby U, Owen MJ, Palotie A, Parr JR, Paterson AD, Pato CN, Pato MT, Penninx BW, Pergadia ML, Pericak-Vance MA, Pickard BS, Pimm J, Piven J, Posthuma D, Potash JB, Poustka F, Propping P, Puri V, Quested DJ, Quinn EM, Ramos-Quiroga JA, Rasmussen HB, Raychaudhuri S, Rehnstrom K, Reif A, Ribases M, Rice JP, Rietschel M, Roeder K, Roeyers H, Rossin L, Rothenberger A, Rouleau G, Ruderfer D, Rujescu D, Sanders AR, Sanders SJ, Santangelo SL, Sergeant JA, Schachar R, Schalling M, Schatzberg AF, Scheftner WA, Schellenberg GD, Scherer SW, Schork NJ, Schulze TG, Schumacher J, Schwarz M, Scolnick E, Scott LJ, Shi JX, Shilling PD, Shyn SI, Silverman JM, Slager SL, Smalley SL, Smit JH, Smith EN, Sonuga-Barke EJS, St Clair D, State M, Steffens M, Steinhausen HC, Strauss JS, Strohmaier J, Stroup TS, Sutcliffe JS, Szatmari P, Szelinger S, Thirumalai S, Thompson RC, Todorov AA, Tozzi F, Treutlein J, Uhr M, van den Oord EJCG, Van Grootheest G, Van Os J, Vicente AM, Vieland VJ, Vincent JB, Visscher PM, Walsh CA, Wassink TH, Watson SJ, Weissman MM, Werge T, Wienker TF, Wijsman EM, Willemsen G, Williams N, Willsey AJ, Witt SH, Xu W, Young AH, Yu TW, Zammit S, Zandi PP, Zhang P, Zitman FG, Zollner S, Devlin B, Kelsoe JR, Sklar P, Daly MJ, O'Donovan MC, Craddock N, Sullivan PF, Smoller JW, Kendler KS, Wray NR, Genomi C-DGP, Genetic IIBD (2013) Genetic relationship between five psychiatric disorders estimated from genome-wide SNPs. Nature Genet 45 (9):984

Leggio L, Kenna GA, Fenton M, Bonenfant E, Swift RM (2009) Typologies of alcohol dependence. From Jellinek to genetics and beyond. Neuropsychol Rev 19(1):115-129

Lesch KP, Gutknecht L (2005) Pharmacogenetics of the serotonin transporter. Prog Neuropsychopharmacol Biol Psychiatry 29(6):1062-1073

Lesch OM, Walter H (1996) Subtypes of alcoholism and their role in therapy. Alcohol Alcohol Suppl 31(1):63-67

Liang W, Chikritzhs T (2015) Age at first use of alcohol predicts the risk of heavy alcohol use in early adulthood: a longitudinal study in the United States. Int J Drug Policy 26(2):131-134

Lin SC, Wu PL, Ko HC, Wu JY, Huang SY, Lin WW, Lu RB (2007) Specific personality traits and dopamine, serotonin genes in anxiety-depressive alcoholism among Han Chinese in Taiwan. Prog Neuropsychopharmacol Biol Psychiatry 31(7):1526-1534

Linnoila M, Virkkunen M, Scheinin M, Nuutila A, Rimon R, Goodwin FK (1983) Low cerebrospinal fluid 5-hydroxyindoleacetic acid concentration differentiates impulsive from nonimpulsive violent behavior. Life Sci 33(26):2609-2614
Lo M-T, Hinds DA, Tung JY, Franz C, Fan C-C, Wang Y, Smeland OB, Schork A, Holland D, Kauppi K (2016) Genome-wide analyses for personality traits identify six genomic loci and show correlations with psychiatric disorders. Nature Genet 49:152-156

Lu RB, Lee JF, Huang SY, Lee SY, Chang YH, Kuo PH, Chen SL, Chen SH, Chu CH, Lin WW, Wu PL, Ko HC (2012) Interaction between ALDH2*1*1 and DRD2/ANKK1 TaqI A1A1 genes may be associated with antisocial personality disorder not comorbid with alcoholism. Addict Biol 17(5):865-874. doi:10. 1111/j.1369-1600.2010.00268.x

Matsushita S, Yoshino A, Murayama M, Kimura M, Muramatsu T, Higuchi S (2001) Association study of serotonin transporter gene regulatory region polymorphism and alcoholism. Am J Med Genet 105(5):446-450. doi:10.1002/ajmg.1405

Merenäkk L, Mäestu J, Nordquist N, Parik J, Oreland L, Loit H-M, Harro J (2011) Effects of the serotonin transporter (5-HTTLPR) and $\alpha 2 \mathrm{~A}$-adrenoceptor (C-1291G) genotypes on substance use in children and adolescents: a longitudinal study. Psychopharmacology 215(1):13-22

Meyer-Lindenberg A, Weinberger DR (2006) Intermediate phenotypes and genetic mechanisms of psychiatric disorders. Nat Rev Neurosci 7(10):818-827

Miettunen J, Veijola J, Lauronen E, Kantojarvi L, Joukamaa M (2007) Sex differences in Cloninger's temperament dimensions-a meta-analysis. Compr Psychiatry 48(2):161-169

Mulder RT (2002) Alcoholism and personality. Aust N Z J Psychiatry $36(1): 44-52$

Munafo MR, Zammit S, Flint J (2014) A critical perspective on geneenvironment interaction models-what impact should they have on clinical perceptions and practice? J Child Psychol Psychiatry 55:1092-1101

Munafò MR, Brown SM, Hariri AR (2008) Serotonin transporter (5HTTLPR) genotype and amygdala activation: a meta-analysis. Biol Psychiatry 63(9):852-857

Nakamura M, Ueno S, Sano A, Tanabe H (2000) The human serotonin transporter gene linked polymorphism (5-HTTLPR) shows ten novel allelic variants. Mol Psychiatry 5(1):32-38

Naoi M, Riederer P, Maruyama W (2016) Modulation of monoamine oxidase (MAO) expression in neuropsychiatric disorders: genetic and environmental factors involved in type A MAO expression. J Neural Trans 123(2):91-106

Nestler EJ (2000) Genes and addiction. Nat Genet 26(3):277-281

Nilsson KW, Comasco E, Hodgins S, Oreland L, Aslund C (2014) Genotypes do not confer risk for delinquency but rather alter susceptibility to positive and negative environmental factors: gene-environment interactions of BDNF Val66Met, 5-HTTLPR, and MAOA-uVNTR [corrected]. Int J Neuropsychopharmacol Off Sci J Coll Int Neuropsychopharmacol 18(5):pii: pyu107. doi:10.1093/ijnp/pyu107.

Noble EP, Ozkaragoz TZ, Ritchie TL, Zhang X, Belin TR, Sparkes RS (1998) D 2 and D 4 dopamine receptor polymorphisms and personality. Am J Med Genet 81(3):257-267

Nolen-Hoeksema S (2004) Gender differences in risk factors and consequences for alcohol use and problems. Clin Psychol Rev 24(8):981-1010

Nordquist N, Oreland L (2010) Serotonin, genetic variability, behaviour, and psychiatric disorders-a review. Upsala J Med Sci 115(1):2-10

Pascale E, Ferraguti G, Codazzo C, Passarelli F, Mancinelli R, Bonvicini C, Bruno s, Lucarelli M, Ceccanti M (2015) Alcohol dependence and serotonin transporter functional polymorphisms 5-HTTLPR and rs25531 in an Italian population. Alcohol Alcohol 50(3):259-265

Pentkowski NS, Duke FD, Weber SM, Pockros LA, Teer AP, Hamilton EC, Thiel KJ, Neisewander JL (2010) Stimulation of 
medial prefrontal cortex serotonin 2C (5-HT2C) receptors attenuates cocaine-seeking behavior. Neuropsychopharmacology 35(10):2037-2048

Perry JL, Carroll ME (2008) The role of impulsive behavior in drug abuse. Psychopharmacology 200(1):1-26

Pezawas L, Meyer-Lindenberg A, Drabant EM, Verchinski BA, Munoz KE, Kolachana BS, Egan MF, Mattay VS, Hariri AR, Weinberger DR (2005) 5-HTTLPR polymorphism impacts human cingulate-amygdala interactions: a genetic susceptibility mechanism for depression. Nat Neurosci 8(6):828-834

Philibert RA, Gunter TD, Beach SR, Brody GH, Madan A (2008) MAOA methylation is associated with nicotine and alcohol dependence in women. Am J Med Genet Part B Neuropsychiatr Genet 147(5):565-570

Pockros LA, Pentkowski NS, Swinford SE, Neisewander JL (2011) Blockade of 5-HT2A receptors in the medial prefrontal cortex attenuates reinstatement of cue-elicited cocaine-seeking behavior in rats. Psychopharmacology 213(2-3):307-320

Pombo S, da Costa NF, Figueira ML, Ismail F, Lesch OM (2015) Multidimensional alcoholism typologies: could they guide clinical practice? Results from a 3-month prospective study. Int J Psychiatry Clin Pract 19(2):137-147

Ponce G, Jimenez-Arriero MA, Rubio G, Hoenicka J, Ampuero I, Ramos JA, Palomo T (2003) The A1 allele of the DRD2 gene (TaqI A polymorphisms) is associated with antisocial personality in a sample of alcohol-dependent patients. Euro Psychiatry $\mathrm{J}$ Asso Euro Psychiatr 18(7):356-360

Prescott CA (2002) Sex differences in the genetic risk for alcoholism. Alcohol Res Health J Natl Inst Alcohol Abus Alcoholism 26(4):264-273

Preuss UW, Koller G, Bondy B, Bahlmann M, Soyka M (2001) Impulsive traits and 5-HT2A receptor promoter polymorphism in alcohol dependents: possible association but no influence of personality disorders. Neuropsychobiology 43(3):186-191

Rasetti R, Weinberger DR (2011) Intermediate phenotypes in psychiatric disorders. Curr Opin Genet Dev 21(3):340-348

Reif A, Lesch K-P (2003) Toward a molecular architecture of personality. Behav Brain Res 139(1):1-20

Reiss D, Leve LD, Neiderhiser JM (2013) How genes and the social environment moderate each other. Am J Public Health 103(Suppl 1):S111-S121

Rezvani AH, Cauley MC, Levin ED (2014) Lorcaserin, a selective 5-HT 2C receptor agonist, decreases alcohol intake in female alcohol preferring rats. Pharmacol Biochem Behav 125:8-14

Rogers CR, Dymond RF (ed) (1954) Psychotherapy and personality change; Co-Ordinated research studies in the client-centered approach. University of Chicago Press, Chicago

Rogers RD, Moeller FG, Swann AC, Clark L (2010) Recent research on impulsivity in individuals with drug use and mental health disorders: implications for alcoholism. Alcohol Clin Exp Res 34(8):1319-1333

Rubens M, Ramamoorthy V, Attonito J, Saxena A, Appunni S, Shehadeh N, Dévieux JG (2016) A review of 5-HT transporter linked promoter region (5-HTTLPR) polymorphism and associations with alcohol use problems and sexual risk behaviors. J Comm Genet 7(1):1-10

Samochowiec J, Kucharska-Mazur J, Rybakowski F, Ostapowicz A, Horodnicki J, Rozpara M, Kamiński R, Skrzypińska A, Arentowicz G, Rommelspacher H (2002) Norepinephrine transporter polymorphism and personality trait of reward dependence in male alcoholics. Pharmacopsychiatry 35(05):195-196

Sanchis-Segura C, Becker J (2016) Why we should consider sex (and study sex differences) in addiction research. Addict Biol 21(5):995-1006

Sander T, Harms H, Dufeu P, Kuhn S, Rommelspacher H, Schmidt LG (1997) Dopamine D4 receptor exon III alleles and variation of novelty seeking in alcoholics. Am $\mathrm{J}$ Med Genet 74(5):483-487

Sander T, Harms H, Dufeu P, Kuhn S, Hoehe M, Lesch KP, Rommelspacher H, Schmidt LG (1998) Serotonin transporter gene variants in alcohol-dependent subjects with dissocial personality disorder. Biol Psychiatry 43(12):908-912. doi:10. 1016/S0006-3223(97)00356-9

Sander T, Ostapowicz A, Samochowiec J, Smolka M, Rommelspacher H, Winterer G, Schmidt LG (2000) Evaluation of an allelic association of the serotonin 5-HT1B G681C polymorphism with antisocial alcoholism in the German population. Addict Biol 5(2):167-172. doi:10.1080/13556210050003757

Shukla SD, Velazquez J, French SW, Lu SC, Ticku MK, Zakhari S (2008) Emerging role of epigenetics in the actions of alcohol. Alcohol Clin Exp Res 32(9):1525-1534

Sjöberg RL, Nilsson KW, Nordquist N, Öhrvik J, Leppert J, Lindström L, Oreland L (2006) Development of depression: sex and the interaction between environment and a promoter polymorphism of the serotonin transporter gene. Int J Neuropsychopharmacol 9(4):443-449

Skinner BF (1950) Are theories of learning necessary? Psychol Rev 57(4): 193

Slutske WS, Heath AC, Madden PA, Bucholz KK, Statham DJ, Martin NG (2002) Personality and the genetic risk for alcohol dependence. J Abnorm Psychol 111(1):124-133

Smoller JW, Craddock N, Kendler K, Lee PH, Neale BM, Nurnberger JI, Ripke S, Santangelo S, Sullivan PF, Consortium PG (2013) Identification of risk loci with shared effects on five major psychiatric disorders: a genome-wide analysis. Lancet 381(9875):1371-1379

Soyka M, Preuss UW, Koller G, Zill P, Bondy B (2002) Dopamine D 4 receptor gene polymorphism and extraversion revisited: results from the Munich gene bank project for alcoholism. J Psychiatr Res 36(6):429-435

Soyka M, Preuss UW, Koller G, Zill P, Bondy B (2004a) Association of 5-HT1B receptor gene and antisocial behavior in alcoholism. J Neural Trans (Vienna, Austria : 1996) 111(1):101-109

Soyka M, Preuss UW, Koller G, Zill P, Hesselbrock V, Bondy B (2004b) No association of CRH1 receptor polymorphism haplotypes, harm avoidance and other personality dimensions in alcohol dependence: results from the Munich gene bank project for alcoholism. Addict Biol 9(1):73-79. doi:10.1080/ 13556210410001674121

Soyka M, Zill P, Koller G, Samochowiec A, Grzywacz A, Preuss UW (2013) Val158Met COMT polymorphism and risk of aggression in alcohol dependence. Addict Biol 20(1):197-204

Stevens L, Verdejo-García A, Goudriaan AE, Roeyers H, Dom G, Vanderplasschen W (2014) Impulsivity as a vulnerability factor for poor addiction treatment outcomes: a review of neurocognitive findings among individuals with substance use disorders. J Subst Abuse Treat 47(1):58-72

Stoltenberg SF, Twitchell GR, Hanna GL, Cook EH, Fitzgerald HE, Zucker RA, Little KY (2002) Serotonin transporter promoter polymorphism, peripheral indexes of serotonin function, and personality measures in families with alcoholism. Am J Med Genet 114(2):230-234. doi:10.1002/ajmg.10187

Thome J, Weijers HG, Wiesbeck GA, Sian J, Nara K, Boning J, Riederer P (1999) Dopamine D3 receptor gene polymorphism and alcohol dependence: relation to personality rating. Psychiatr Genet 9(1):17-21

Todkar A, Nilsson KW, Oreland L, Hodgins S, Comasco E (2013) Serotonin transporter genotype by environment: studies on alcohol use and misuse in non-human and human primates. Transl Neurosci 4(2):241-250

Toffoletto S, Lanzenberger R, Gingnell M, Sundstrom-Poromaa I, Comasco E (2014) Emotional and cognitive functional imaging 
of estrogen and progesterone effects in the female human brain: a systematic review. Psychoneuroendocrinology 50:28-52

Tragesser SL, Sher KJ, Trull TJ, Park A (2007) Personality disorder symptoms, drinking motives, and alcohol use and consequences: cross-sectional and prospective mediation. Exp Clin Psychopharm 15(3):282-292

Vaht M, Merenäkk L, Mäestu J, Veidebaum T, Harro J (2014) Serotonin transporter gene promoter polymorphism (5-HTTLPR) and alcohol use in general population: interaction effect with birth cohort. Psychopharmacology 231(13):2587-2594

Vaht M, Kiive E, Veidebaum T, Harro J (2016) A functional vesicular monoamine transporter 1 (VMAT1) gene variant is associated with affect and the prevalence of anxiety, affective and alcohol use disorders in a longitudinal population-representative birth cohort study. Int Neuropsychopharmacol 19(7). doi:10.1093/ ijnp/pyw013

von Knorring A-L, Hallman J, von Knorring L, Oreland L (1991) Platelet monoamine oxidase activity in type 1 and type 2 alcoholism. Alcohol Alcohol 26(4):409-416

Walderhaug E, Magnusson A, Neumeister A, Lappalainen J, Lunde H, Refsum H, Landrø NI (2007) Interactive effects of sex and 5-HTTLPR on mood and impulsivity during tryptophan depletion in healthy people. Biol Psychiatry 62(6):593-599

Wang KS, Liu X, Aragam N, Mullersman JE, Jian X, Pan Y, Liu Y (2012) Polymorphisms in ABLIM1 are associated with personality traits and alcohol dependence. J Mol Neurosci 46(2):265-271

Wang TY, Lee SY, Chen SL, Huang SY, Chang YH, Tzeng NS, Wang CL, Hui Lee I, Yeh TL, Yang YK, Lu RB (2013) Association between DRD2, 5-HTTLPR, and ALDH2 genes and specific personality traits in alcohol- and opiate-dependent patients. Behav Brain Res 250:285-292. doi:10.1016/j.bbr. 2013.05.015

Weidenfeld J, Newman ME, Itzik A, Gur E, Feldman S (2002) The amygdala regulates the pituitary-adrenocortical response and release of hypothalamic serotonin following electrical stimulation of the dorsal raphe nucleus in the rat. Neuroendocrinology 76(2):63-69

Weijers HG, Wiesbeck GA, Wodarz N, Keller H, Michel T, Böning J (2003) Gender and personality in alcoholism. Arch Womens Ment Health 6(4):245-252

Whelan R, Watts R, Orr CA, Althoff RR, Artiges E, Banaschewski T, Barker GJ, Bokde AL, Büchel C, Carvalho FM (2014) Neuropsychosocial profiles of current and future adolescent alcohol misusers. Nature 512(7513):185-189

Whiteside SP, Lynam DR (2003) Understanding the role of impulsivity and externalizing psychopathology in alcohol abuse: application of the UPPS impulsive behavior scale. Exp Clin Psychopharm 11(3):210

Wiesbeck GA, Weijers HG, Wodarz N, Keller HK, Michel TM, Herrmann MJ, Boening J (2004) Serotonin transporter gene polymorphism and personality traits in primary alcohol dependence. World J Biol Psychiatry Off J World Fed Soc Biol Psychiatry 5(1):45-48

Wittchen HU, Jacobi F, Rehm J, Gustavsson A, Svensson M, Jonsson B, Olesen J, Allgulander C, Alonso J, Faravelli C, Fratiglioni L, Jennum P, Lieb R, Maercker A, van Os J, Preisig M, SalvadorCarulla L, Simon R, Steinhausen HC (2011) The size and burden of mental disorders and other disorders of the brain in Europe 2010. Eur Neuropsychopharmacol 21(9):655-679

Wu CY, Wu YS, Lee JF, Huang SY, Yu L, Ko HC, Lu RB (2008) The association between DRD2/ANKK1, 5-HTTLPR gene, and specific personality trait on antisocial alcoholism among Han Chinese in Taiwan. Am J Med Genet Part B Neuropsychiatr Genet Off Publ Int Soc Psychiatr Genet 147B(4):447-453

Zuckerman M, Bone RN, Neary R, Mangelsdorff D, Brustman B (1972) What is the sensation seeker? Personality trait and experience correlates of the Sensation-Seeking Scales. J Consult Clin Psychol 39(2):308 